\title{
The ReFOLD assay for protein formulation studies and prediction of protein aggregation during long-term storage
}

\author{
Hristo Svilenov*, Gerhard Winter \\ Department of Pharmacy, Pharmaceutical Technology and Biopharmaceutics, Ludwig-Maximilians-University, \\ Butenandtstrasse 5-13, Munich D-81377, Germany \\ *Corresponding author: hrisph@cup.uni-muenchen.de
}

\begin{abstract}
The formulation of novel therapeutic proteins is a challenging task which aims at finding formulation conditions that will minimize protein degradation during long-term storage. One particularly important and difficult-to-predict protein degradation pathway is the so-called non-native aggregation. The qualitative and quantitative prediction of the latter has been a subject of extensive research over the past two decades. An increasing body of evidence shows that the widely-used short-term biophysical techniques cannot accurately rank formulation conditions in order of their effect on the aggregation during long-term storage of some therapeutic proteins, e.g. monoclonal antibodies. Here we suggest a novel approach for the selection of formulation conditions that will suppress the formation of protein aggregates during long-term storage. We postulate that conditions (i.e. $\mathrm{pH}$, buffer type, ionic strength) that reduce the isothermal aggregation of various denaturant-induced partially folded protein species will be conditions that impede protein aggregation during long-term storage. To test our hypothesis, we developed an isothermal microdialysis-based unfolding/refolding assay, named ReFOLD, which we use to induce moderate aggregation of partially folded proteins. Next, we assessed the relative monomer yield after isothermal unfolding/refolding of two monoclonal antibodies, each formulated in 12 different conditions. Using the proposed approach, we were able to accurately rank the formulations in order of their effect on the amount of protein aggregates detected after storage for 12 months at $4{ }^{\circ} \mathrm{C}$ and $25^{\circ} \mathrm{C}$, while widely-used stability-indicating parameters like protein melting and aggregation onset temperatures failed to provide accurate predictive formulation rankings.
\end{abstract}


Schematic diagram of the ReFOLD assay
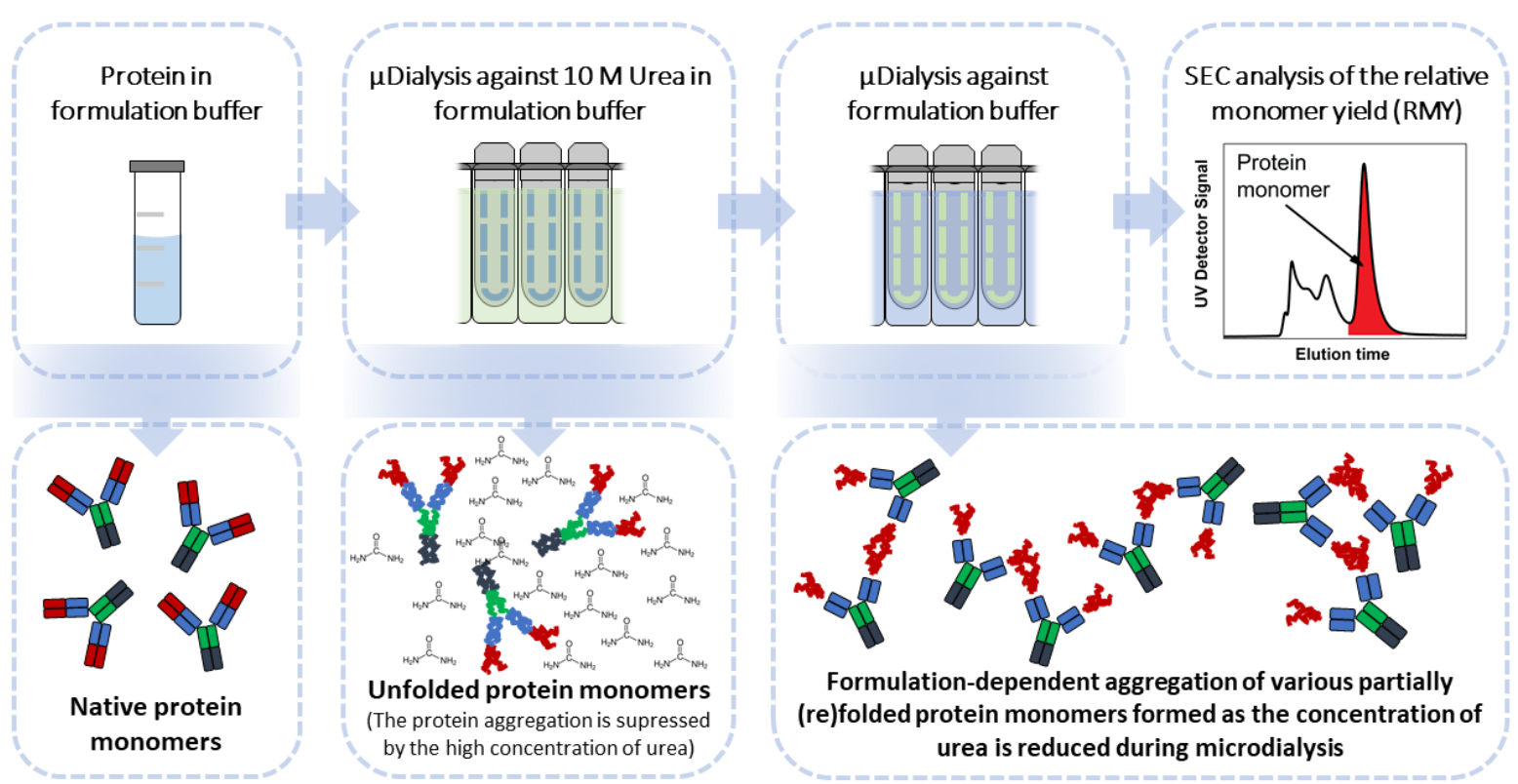

\section{KEYWORDS}

Proteins; Protein formulation; Protein folding; Protein unfolding; Protein Aggregation; Monoclonal antibody; Storage Stability; Stability prediction;

\section{ABBREVIATIONS}

CD - Circular dichroism;

dG - the Gibbs free energy of protein unfolding;

DLS - Dynamic Light Scattering;

DSF - Differential Scanning Fluorimetry;

ICD - Isothermal Chemical Denaturation;

mAb-monoclonal antibody;

nanoDSF ${ }^{\mathrm{TM}}$ - Microscale Differential Scanning Fluorimetry;

RMY - Relative Monomer Yield after refolding;

SEC-MALS - size exclusion chromatography coupled to a multi-angle light scattering detector;

$\mathrm{T}_{\text {agg }}$ - Protein aggregation onset temperature;

$\mathrm{T}_{\mathrm{m}}$ - Protein melting temperature; 


\section{INTRODUCTION}

Non-native protein aggregation (referred to as just "protein aggregation" in this paper) is a major concern during the long-term storage of liquid protein formulations ${ }^{1-4}$. This pathway of protein aggregation typically occurs through partially unfolded intermediates (often termed as reactive species ${ }^{5}$ ), which can form irreversible aggregate nuclei that can further grow by various mechanisms. The latter are extensively discussed in the literature and are outside the scope of this article $e^{1,6-9}$. Regardless of the exact mechanism of aggregate nucleation and growth, the formation and presence of protein aggregates in parenteral products should be controlled and minimized for various reasons, e.g. immunogenicity concerns ${ }^{10-13}$, reduced biological activity ${ }^{14,15}$ or non-compliance with regulatory frameworks ${ }^{16-18}$. The formation of protein aggregates during long-term storage can be suppressed by choosing suitable formulation conditions, e.g. $\mathrm{pH}$, buffer type, ionic strength, etc. ${ }^{19,20}$. The process of selecting the optimal formulation for a new therapeutic protein candidate usually includes the testing of dozens of different conditions ${ }^{21,22}$. Screening all these formulation conditions with long-term and/or accelerated stability studies is impractical as this would require a lot of resources. Therefore, many researchers turn to short-term biophysical techniques that could provide predictions for the protein aggregation during storage, thereby reducing the number of formulations for long-term stability studies.

Such biophysical techniques usually require small amounts of sample, can be performed in short timeframes and are suitable for automatization and high-throughput formats ${ }^{23-26}$. Two of these techniques that are frequently used in the industry are differential scanning fluorimetry (DSF) and dynamic light scattering (DLS) ${ }^{4,27-32}$. The latter can provide the (apparent) protein melting temperature $\left(T_{m}\right)$ and the aggregation onset temperature $\left(T_{a g g}\right)$ respectively. Earlier publications show that in some cases, and on a limited set of formulation conditions, a high $\mathrm{T}_{\mathrm{m}}$ or a high $\mathrm{T}_{\mathrm{agg}}$ can be an indicator for formulation conditions where protein aggregation is suppressed during accelerated stability studies (e.g. $40{ }^{\circ} \mathrm{C}$ and $\left.50{ }^{\circ} \mathrm{C}\right)^{4,33,34}$. However, recent work on larger sets of proteins indicates that these parameters show a very weak or no correlation with the aggregation behaviour of many therapeutic proteins, especially mAbs, during storage at $4{ }^{\circ} \mathrm{C}$ and $25^{\circ} \mathrm{C}^{21,33,35,36}$.

Probably due to the above-mentioned reason, researchers have started to explore orthogonal techniques that could provide better stability predictions for the aggregation behaviour of novel therapeutic proteins during long-term storage. One such technique is isothermal chemical denaturation (ICD) $)^{31,37,38}$. Although ICD is the gold standard to obtain the Gibbs free energy of protein unfolding (and thereby assess the conformational stability of a protein) ${ }^{39}$, the data evaluation from this method is valid only in cases where the protein of interest undergoes reversible unfolding in the denaturant solution ${ }^{40-42}$. Most of the published work including ICD experiments is on small globular 
single-domain proteins ${ }^{43-45}$. However, the vast majority of therapeutic proteins under development in the moments have large, multi-domain structures (e.g. mAbs, bispecifics, fusion proteins, antibodydrug conjugates) that can undergo complex, multi-step unfolding during an ICD experiment which could require sophisticated fitting to a mode $\left.\right|^{31,46}$. Furthermore, the reversibility of unfolding of these proteins in different formulation conditions might vary ${ }^{37,40,41}$. Recently, it was suggested that one could use ICD experiments to investigate non-reversibility effects during protein unfolding in a denaturant ${ }^{47,48}$. Such experiments study how the apparent Gibbs free energy of protein unfolding changes when different protein concentrations are used to obtain the ICD curves. It was already demonstrated that the latter approach can provide complementary stability-indicating information to DSF and DLS ${ }^{37,49}$. Still, ICD experiments that study the concentration dependence of dG are tedious, require dedicated laboratory equipment and rely on the quality of the fitting to a certain unfolding model.

Rather than using ICD as an "indirect" way to look into the effect of the formulation conditions on the reversibility of isothermal protein unfolding, we recently suggested that one could directly study the aggregation after dilution from a denaturant ${ }^{40}$. Shortly after that and independently of us, Rowe et al. suggested a similar approach ${ }^{50}$. In our previous work, we showed that when the dilution refolding experiments are performed with certain denaturant concentrations, the protein aggregation during refolding can be linked to other stability-indicating parameters, e.g. the melting denaturant concentration $C_{m}$ and the interaction parameter $k_{D}{ }^{40}$. The dilution approach we proposed is valuable to probe which denaturant concentrations will cause extensive protein aggregation after dilution refolding and also to study if there is a difference in the physical stability of a protein in conditions with overlapping ICD curves $^{40}$.

However, different concentrations of a denaturant cause different degrees of protein unfolding and different aggregation-prone intermediates. Each of the latter could be important for the non-native protein aggregation during long-term storage. Rather than diluting the protein from dozens of different denaturant concentrations, we decided to perform microdialysis on the protein against a denaturant and subsequently against a denaturant-free formulation buffer. This procedure will cause various unfolding (refolding) protein intermediates. We hypothesized that these intermediates will aggregate depending on the formulation conditions, e.g. $\mathrm{pH}$, buffer type, ionic strength, protein concentration. The rationale behind using this phenomenon as a protein formulation tool is that formulation conditions which suppress the aggregation of various partially folded states would be formulation conditions that would suppress protein aggregation during long-term storage. Since the isolation of the individual aggregation-prone intermediates or aggregates formed could be a challenging task, we adopted an approach where we assess the relative monomer yield (RMY) after 
the isothermal unfolding and refolding is completed. Important to note, assessing the RMY after isothermal unfolding/refolding of the protein for the purpose of formulation development would be quite different compared to unfolding/refolding experiments to increase the monomer yield after protein expression as inclusion bodies. The latter experiments usually include a reduction and new formation of disulphide bonds, as well as extremities in the $\mathrm{pH}$, excipient concentration and the type of excipients used ${ }^{51-55}$. Assessing the aggregation during isothermal unfolding/refolding of the protein as a formulation tool is focused on a $\mathrm{pH}$ range which is realistic for long-term storage and administration in patients due to chemical stability and tolerability considerations respectively. Furthermore, the excipients used, as well as their concentrations, would be approved for parenteral application $^{56}$.

To study our hypothesis, we developed a microdialysis unfolding/refolding assay which we called ReFOLD. Next, we studied the effect of realistic for long-term storage formulation conditions on the relative monomer yield after isothermal unfolding/refolding of two monoclonal antibodies. We validated the predictions from the ReFOLD assay by performing 12 -month stability study at $4{ }^{\circ} \mathrm{C}$ and $25{ }^{\circ} \mathrm{C}$. Additionally, we characterized the antibodies in the presence of urea to show that this denaturant causes partially unfolded states and suppresses the protein aggregation in all conditions tested. The latter phenomena allow us to see formulation-dependent differences in the monomer loss caused by aggregation of partially folded protein species during unfolding/refolding.

\section{MATERIALS AND METHODS}

\subsection{Monoclonal antibodies and chemicals}

Two IgG1 monoclonal antibodies were used in this work - LMU-1 and PPI03. The monomeric state and the purity of the proteins in the bulk solution were confirmed as described earlier ${ }^{40}$.

The buffer of the mAbs was exchanged by extensive dialysis overnight as previously described ${ }^{40}$. Unless otherwise stated, the final mAb solutions after dialysis contained $10 \mathrm{mM}$ histidine/histidine hydrochloride buffer, $10 \mathrm{mM}$ sodium citrate/citric acid buffer with a pH 5, 5.75 or 6.5. The PPI03 samples containing $70 \mathrm{mM}$ sodium chloride were prepared by spiking in the salt from a 10X stock solution. All LMU-1 samples contained 0,05 \% w/v polysorbate 20 which was spiked in the protein solution after dialysis. All PPI03 solutions were free of surfactants. For an overview of the formulations see Tables 1, S1 and S2. The protein concentration was measured by UV spectrometry at $280 \mathrm{~nm}$ with a Nanodrop 2000 (Thermo Fisher Scientific, Wilmington, DE) using the respective protein extinction coefficient. 
Reagent chemicals from the highest grade available were purchased from Sigma Aldrich (Steinheim, Germany), VWR International (Darmstadt, Germany) or Fisher Scientific (Schwerte, Germany). Highly purified water was used for the preparation of all buffers.

\subsection{Isothermal protein unfolding and refolding with microdialysis (the ReFOLD assay)}

$100 \mu \mathrm{L}$ of formulated mAb solution was filled in Pierce ${ }^{\mathrm{TM}}$ microdialysis devices with a membrane having 3.5 kDa MWCO. The samples were dialyzed in a deep well-plate against $1.5 \mathrm{~mL}$ of $10 \mathrm{M}$ urea solution in the respective formulation buffer. The urea solution was changed 4 and 8 hours after the beginning. After the last change, the dialysis was continued for another 16 hours. Next, the mAb samples dialyzed against $10 \mathrm{M}$ urea were dialyzed against $1.5 \mathrm{~mL}$ of the respective urea-free formulation buffer. The buffer was changed 4 and 8 hours after the beginning, the dialysis continued in total for 24 hours. During the entire dialysis procedure, the deep well plate was attached to a Thermomixer Comfort (Eppendorf AG, Hamburg, Germany) which was adjusted to agitate the plate at $700 \mathrm{rpm}$. Finally, the samples were collected from the dialysis devices and the weight of each sample was added to $1.0 \mathrm{~g}$ with the respective urea-free buffer to avoid variations in the sample volume that might arise during dialysis. Finally, the samples were centrifuged at $10000 \times \mathrm{g}$ for 10 minutes to remove any insoluble matter. The supernatant was used for further measurements.

\subsection{Size Exclusion Chromatography (SEC)}

A Dionex Summit 2 system (Thermo Fisher, Dreieich, Germany) and a TSKgel G3000SWxl, 7,8x300 mm, $5 \mu \mathrm{m}$ column (Tosoh Bioscience, Tokyo, Japan) were used for the size exclusion chromatography. Protein elution was detected at $280 \mathrm{~nm}$ unless otherwise stated. The running buffer consisted of 100 $\mathrm{mM}$ potassium phosphate, $200 \mathrm{mM}$ sodium chloride and $0,05 \% \mathrm{w} / \mathrm{v}$ sodium azide. The buffer $\mathrm{pH}$ was adjusted to 7.0 with $2 \mathrm{M}$ sodium hydroxide. The chromatograms were integrated with Chromeleon V6.8 (Thermo Fisher, Dreieich, Germany). The relative content of the high molecular weight (HMW) species formed after long-term storage was calculated by dividing the peak area of the high molecular weight species by the total area of all protein peaks in the chromatogram which provides a number representing the relative content of high molecular weight species in percentage. Representative chromatograms with integration times and more explanations are presented in Fig S1. The relative monomer yield (RMY) of the proteins after isothermal unfolding/refolding, i.e. the ReFOLD assay, was calculated by dividing the area of the monomer peak of the refolded sample by the area of the monomer peak of the sample before unfolding/refolding which gives a value between 0 and 1 , where 0 means that no protein monomer is recovered in the sample after refolding and 1 means the same amount of monomer is recovered after refolding. 


\subsection{Size Exclusion Chromatography with Multi-angle Light Scattering Detector (SEC-MALS)}

An Agilent 1100 Series HPLC system (Santa Clara, CA, USA) with an Agilent 1100 multiple wavelength detector (Santa Clara, CA, USA), Agilent 1100 refractive index detector and a DAWN HELEOS multiangle light scattering (MALS) detector (Wyatt Technology, Santa Barbara, USA) were used for the SECMALS measurements. Sample elution was monitored at $280 \mathrm{~nm}$ and with the change in the refractive index. The same column and running buffer like for the SEC method above were used. Data collection and processing were performed using the ASTRA software, Version 7.1 (Wyatt Technology, Santa Barbara, USA).

\subsection{Isothermal Chemical Denaturation (ICD)}

Samples for isothermal chemical denaturation experiments were prepared by combining protein stock solution in formulation buffer with different amounts of formulation buffer and $10 \mathrm{M}$ urea stock solution in formulation buffer in a non-binding 384-well plate as described earlier ${ }^{37,40}$. The samples were incubated for 24 hours at room temperature and the protein intrinsic fluorescence intensity at 330 and $350 \mathrm{~nm}$ was measured after excitation at $280 \mathrm{~nm}$ with a FLUOstar Omega microplate reader (BMG Labtech, Ortenberg, Germany). The intrinsic protein fluorescence intensity ratio (FI350/FI330) was plotted against the urea concentration to obtain isothermal chemical unfolding curves of the mAbs in different buffers ${ }^{25,37,40}$.

\subsection{Microscale Differential Scanning Fluorimetry (nanoDSF ${ }^{\mathrm{TM}}$ )}

The protein samples were filled in standard nanoDSF ${ }^{\mathrm{TM}}$ grade capillaries, the capillaries were sealed and the thermal unfolding of the proteins was studied by applying a temperature ramp of $1{ }^{\circ} \mathrm{C} / \mathrm{min}$ from 20 to $100{ }^{\circ} \mathrm{C}$ with the Prometheus NT.48 (NanoTemper Technologies, Munich, Germany) system that measures the intrinsic protein fluorescence intensity at 330 and $350 \mathrm{~nm}$ after excitation at 280 $\mathrm{nm}$. At the same time, the device detects aggregation/precipitation of the samples by measuring the back-reflection intensity of a light beam that passes twice through the capillary, this signal can be normalized to a value called "Excess Scattering". The apparent protein melting temperatures $\left(T_{m}\right)$ were determined with the PR.ThermControl software V2.1 (NanoTemper Technologies, Munich, Germany) from the maximum of the first derivatives of the thermal unfolding curves ${ }^{57,58}$.

\subsection{Circular Dichroism (CD) Spectroscopy}

Near-UV circular dichroic spectra of the mAb samples were measured at $25{ }^{\circ} \mathrm{C}$ with a Jasco J-810 spectrometer (JASCO Deutschland GmbH, Pfungstadt, Germany). Quartz cuvettes (Hellma GmbH, Muellheim, Germany) with $10 \mathrm{~mm}$ wavelength path were used for the measurements. All measurements were performed with 3 accumulations and a speed of $20 \mathrm{~nm} / \mathrm{min}$. The spectrum of the 
respective buffer was subtracted for each sample, Savitzky-Golay algorithm with 9 smoothing points was applied and the mean residue ellipticity (MRE) of the protein at each wavelength was calculated as described elsewhere ${ }^{59}$.

\subsection{Fourier-transform Infrared Spectroscopy (FT-IR)}

FT-IR spectra of the mAb samples were collected at $25^{\circ} \mathrm{C}$ using a Tensor 27 (Bruker Optik GmbH, Ettlingen, Germany) with a BioATR (Attenuated Total Reflectance) cell ${ }^{\mathrm{TM}}$ II (Harrick) connected to a thermostat (DC30-K20, Thermo Haake). 120 scans with a resolution of $4 \mathrm{~cm}^{-1}$ were taken to measure each spectrum. The raw data of each sample was analysed with the Opus 7.5 (Bruker Optik GmbH) software and shown as a vector-normalized second-derivative spectrum. The data were smoothed using a Savitzky-Golay algorithm with 17 smoothing points ${ }^{60}$.

\subsection{Long-term stability studies}

The mAb solutions with different formulation conditions were sterile filtered with a $0.22 \mu \mathrm{m}$ cellulose acetate filter and aseptically filled into pre-sterilized DIN2R glass type I vials (MGlass AG, Germany).

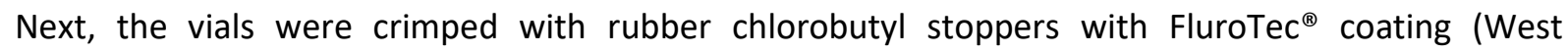
Pharmaceutical Services, USA) and stored at $4{ }^{\circ} \mathrm{C}$ and $25^{\circ} \mathrm{C}$ for the desired time. Three different vials were used for the SEC analysis of each condition.

\section{RESULTS AND DISCUSSION}

\subsection{The isothermal protein unfolding/refolding leads to a formulation-dependent protein aggregation and monomer loss}

Both antibodies used in this work show substantial aggregation after microdialysis against $10 \mathrm{M}$ urea (unfolding) and subsequently against urea-free formulation buffer (refolding). The visual appearance of the samples after refolding is dependent on the formulation conditions in which the refolding is performed. For example, after the ReFOLD assay, LMU-1 formulations with a concentration $10 \mathrm{~g} / \mathrm{L}$ in $10 \mathrm{mM}$ histidine buffer with $\mathrm{pH} 6.5$ remain transparent, while counterparts with $10 \mathrm{mM}$ citrate buffer show increased turbidity and form a pellet after centrifugation. These observations confirm earlier reports that the aggregate formation of antibodies after dilution/dialysis from a denaturant is formulation-dependent ${ }^{40,50}$. SEC-MALS analysis of the supernatant of the refolded samples shows that the samples contain a considerable amount of high molecular weight species ranging from dimers to oligomers larger than $1000 \mathrm{kDa}$. (Figure 1). The aggregates are not reversible, and their relative area is the same even several days after the dialysis (data not shown). A monomer peak having the same retention time as the native protein is detected in the refolded samples. The area of the monomer peak is largely dependent on the formulation buffer in which the ReFOLD assay is performed. Since the evaluation of the exact size, concentration and type of aggregates formed is challenging in such a 
complex mixture, we decided to focus on the fraction of the protein that remains monomeric after isothermal unfolding/refolding (i.e. the relative monomer yield - RMY) as a parameter providing a comparison between the formulations.

Figure 1. SEC-MALS of native and refolded samples of LMU-1 and PPI03.
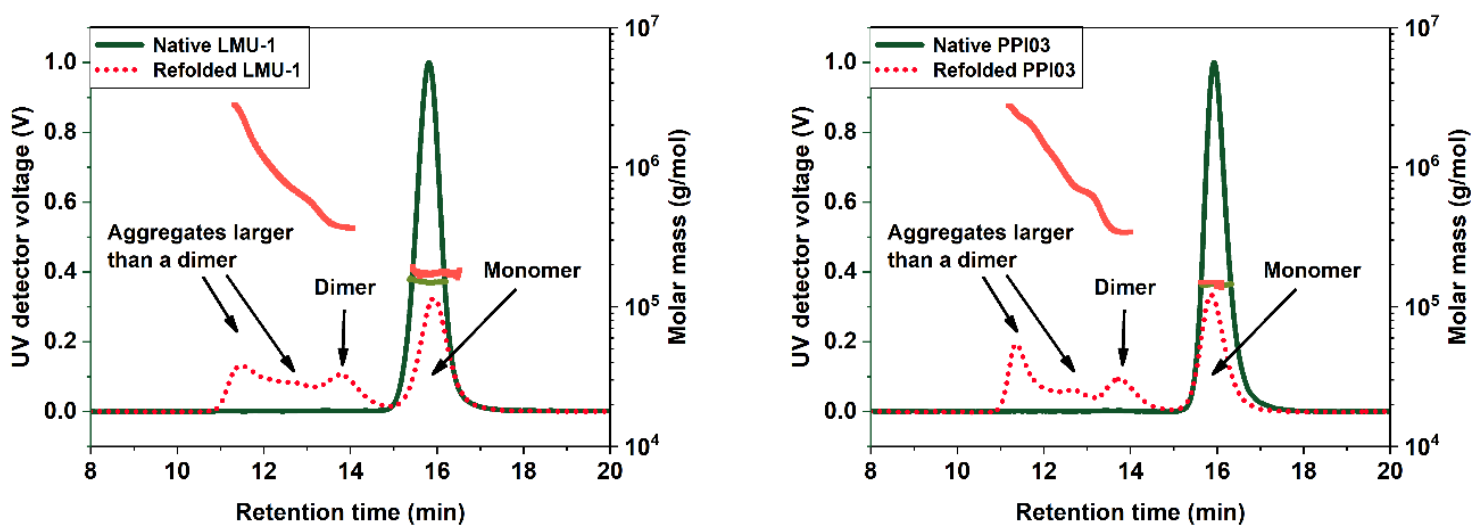

3.2. The relative monomer yield after isothermal protein unfolding/refolding correlates with the relative amount of protein aggregates detected after long-term storage

The relative monomer yield after the ReFOLD assay is highly dependent on the formulation conditions of both LMU-1 (Table 1 and S1) and PPI03 (Table S2). The formulation conditions also have an influence on the relative area of high molecular weight (HMW) species, i.e. protein aggregates, detected by SEC after storing the respective denaturant-free protein samples for 12 months at $4{ }^{\circ} \mathrm{C}$ and $25{ }^{\circ} \mathrm{C}$ (Tables 1, S1 and S2). LMU-1 samples contain more HMW species after long-term storage compared to PPI03. Both proteins form fewer HMW species when stored at $4{ }^{\circ} \mathrm{C}$ compared to storage at $25{ }^{\circ} \mathrm{C}$. We also used flow microscopy to study the presence of subvisible particles in the samples after 12 months of storage at $4{ }^{\circ} \mathrm{C}$ and $25{ }^{\circ} \mathrm{C}$ (Figure S2). Calculations on the monomer recovery from the size-exclusion chromatography method used for the stability study are also included in supplementary data (Tables S3 and S4). A very strong correlation between the relative monomer yield from the ReFOLD assay and the relative area of high molecular weight species detected after 12 months of storage is observed in the case of LMU-1 (Figure 2). Interestingly, the first and second apparent melting temperatures of LMU-1 measured nanoDSF ${ }^{\mathrm{TM}}$ show reversed correlations with the relative area of HMW species detected after storage, therefore providing misleading predictions for the long-term physical stability of these samples (Figures S3 and S4). The aggregation onset temperatures of LMU-1 show only a moderate to weak correlation with the amount of aggregates formed after storage for 12 months (Figure S5). In the case of PPI03 the Spearman's R between the RMY from the ReFOLD assay and the aggregates formed after storage at $4{ }^{\circ} \mathrm{C}$ and $25^{\circ} \mathrm{C}$ is -0.762 and -0.686 respectively, showing a strong correlation between these parameters (Figure S6). Like the case of LMU-1, the melting temperatures 
of the PPI03 samples show an inverse correlation with the aggregates formed after storage, therefore providing wrong predictions for these formulations (Figures S7 and S8). The aggregation onset temperatures of the PPI03 samples show a very weak correlation with the amount of high molecular species formed after long-term storage at $4{ }^{\circ} \mathrm{C}$ and $25^{\circ} \mathrm{C}$ (Figure S9). In general, PPI03 exhibits a very low aggregation propensity and small differences between the formulations during long-term storage. The latter observations can contribute to the lower correlation between the RMY and the aggregates formed after 12 months of storage in comparison to LMU-1. Almost all LMU-1 and PPI03 formulations contain less than 10000 particles $\geq 2 \mu \mathrm{m}$ per $\mathrm{mL}$ after 12 months of storage at $25{ }^{\circ} \mathrm{C}$ and $4{ }^{\circ} \mathrm{C}$ (Figure S2). One exception is the LMU-1 formulation with protein concentration $50 \mathrm{~g} / \mathrm{L}$ formulated in $10 \mathrm{mM}$ histidine $\mathrm{pH} 6.5$ which contains around 150000 particles $\geq 2 \mu \mathrm{m}$ per $\mathrm{mL}$. Interestingly, this is also the formulation with the lowest relative monomer yield after the ReFOLD assay (Table 1). There, are small differences, i.e. $\pm 5 \%$, in the monomer recovery of the antibodies at the end of the stability study. The samples with high RMY from the ReFOLD assay show $100 \%\left( \pm 1 \%\right.$ ) monomer recovery after 12 -month storage at $4{ }^{\circ} \mathrm{C}$ and $25^{\circ} \mathrm{C}$ (Tables S3 and S4).

It is important to underline that the RMY-based predictions from the ReFOLD assay provide reliable ranking of the formulations in order of their effect on the relative area of protein HMWs formed after 12 months of storage at $4{ }^{\circ} \mathrm{C}$ and $25^{\circ} \mathrm{C}$, while often-used stability-indicating parameters (i.e. apparent protein melting temperatures from nanoDSF ${ }^{\mathrm{TM}}$ and the aggregation onset temperatures from dynamic light scattering) provided misleading or weak predictions. 
Table 1. Relative Monomer Yield (RMY) of LMU-1 formulations after the ReFOLD assay and the relative content of high molecular weight species after long term storage of the respective LMU-1 formulations. The values are mean of triplicates and the error represents the standard deviation. The value from each replicate is provided in Table $\mathbf{S 1 .}$

\begin{tabular}{|c|c|c|c|c|c|c|c|c|c|}
\hline \multirow[t]{2}{*}{$\begin{array}{c}\text { Formulation } \\
\text { number }\end{array}$} & \multirow{2}{*}{$\begin{array}{l}\text { Protein } \\
\text { conc. } \\
\text { [g/L] }\end{array}$} & \multirow[t]{2}{*}{ Buffer } & \multirow[t]{2}{*}{$\mathrm{pH}$} & \multicolumn{2}{|c|}{$\begin{array}{l}\text { RMY after refolding } \\
\text { from } 10 \mathrm{M} \text { urea }\end{array}$} & \multicolumn{2}{|c|}{$\begin{array}{l}\% \mathrm{HMW} \text { after } 12 \\
\text { months at } 25^{\circ} \mathrm{C}\end{array}$} & \multicolumn{2}{|c|}{$\begin{array}{c}\% \text { HMW after } 12 \\
\text { months at } 4{ }^{\circ} \mathrm{C}\end{array}$} \\
\hline & & & & Mean & StDev & Mean & StDev & Mean & StDev \\
\hline 1 & 10 & histidine & 5 & 0.387 & 0.0145 & 0.207 & 0.0252 & 0.153 & 0.0513 \\
\hline 2 & 10 & histidine & 5.75 & 0.378 & 0.0125 & 0.167 & 0.0153 & 0.197 & 0.0462 \\
\hline 3 & 10 & histidine & 6.5 & 0.269 & 0.0035 & 0.447 & 0.0907 & 0.283 & 0.0808 \\
\hline 4 & 10 & citrate & 5 & 0.241 & 0.0021 & 0.51 & 0.0346 & 0.313 & 0.0231 \\
\hline 5 & 10 & citrate & 5.75 & 0.168 & 0.0032 & 0.723 & 0.0651 & 0.363 & 0.0586 \\
\hline 6 & 10 & citrate & 6.5 & 0.159 & 0.0067 & 0.94 & 0.1082 & 0.607 & 0.0404 \\
\hline 7 & 50 & histidine & 5 & 0.096 & 0.0032 & 0.703 & 0.0289 & 0.47 & 0.04 \\
\hline 8 & 50 & histidine & 5.75 & 0.083 & 0.0046 & 0.863 & 0.0306 & 0.587 & 0.0723 \\
\hline 9 & 50 & histidine & 6.5 & 0.005 & 0.0038 & 1.607 & 0.0551 & 0.923 & 0.0208 \\
\hline 10 & 50 & citrate & 5 & 0.071 & 0.0052 & 0.977 & 0.0808 & 0.437 & 0.0643 \\
\hline 11 & 50 & citrate & 5.75 & 0.035 & 0.0046 & 1.15 & 0.0819 & 0.593 & 0.0208 \\
\hline 12 & 50 & citrate & 6.5 & 0.021 & 0.0032 & 1.757 & 0.0929 & 1.01 & 0.0755 \\
\hline
\end{tabular}

Figure 2. Correlation between the relative monomer yield of LMU-1 from the ReFOLD assay and the relative content of high molecular weight species, i.e. protein aggregates, detected by size exclusion chromatography after 12 months of storage at $25^{\circ} \mathrm{C}$ (left) and at $4{ }^{\circ} \mathrm{C}$ (right). The value of each replicate is shown on the graph. The solid red line is linear fit of the data, the dark red zone represents the $95 \%$ confidence interval of the fit and the light red zone the $95 \%$ prediction interval.

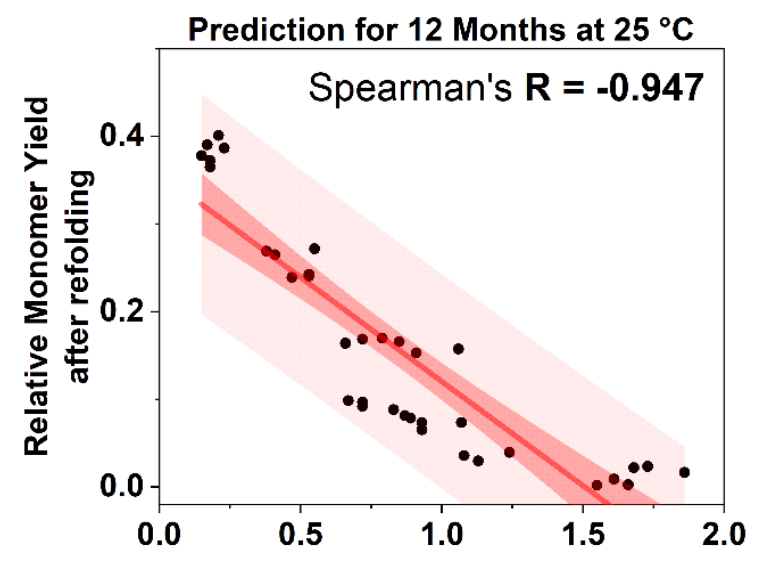

High Molecular Weight Species (\%)

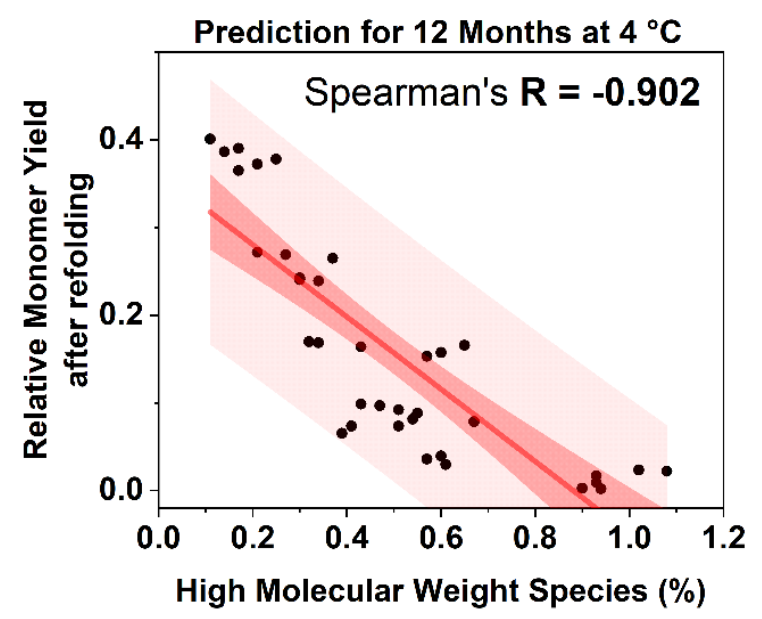

11 


\subsection{Urea causes partially unfolded species, reduces the melting temperatures and suppresses the}

aggregation of LMU-1 and PPI03

To study whether the proteins in this work form partially folded states in urea, we performed isothermal chemical denaturation experiments on all 24 LMU-1 and PPI03 formulations. The isothermal unfolding curves of LMU-1 (Figure 3) and PPIO3 (Figure S10) are dependent on the formulation conditions (i.e. $\mathrm{pH}$, buffer type, sodium chloride concentration). However, in all conditions tested the intrinsic protein fluorescence ratio reached the same value at urea concentration of $9.5 \mathrm{M}$ (around 1.3 in the case of LMU-1 and around 1.2 in the case of PPI03). This indicates that the unfolding was complete at this concentration of urea. The latter was also later confirmed by the loss of the typical peaks in the near-UV CD spectra related to the protein tertiary structure (see below). Our aim by performing the isothermal chemical denaturation experiments was not to fit the data and extract thermodynamic parameters from it. Our purpose was to show that different concentrations of urea cause different states of the unfolding of the protein in the formulations tested.

Figure 3. Isothermal unfolding curves of LMU-1 in different formulation buffers. The symbols are means of triplicates and the bars represent the standard deviation. The lines are a guide to the eye. The concentration of LMU-1 in all samples is $1 \mathrm{~g} / \mathrm{L}$.

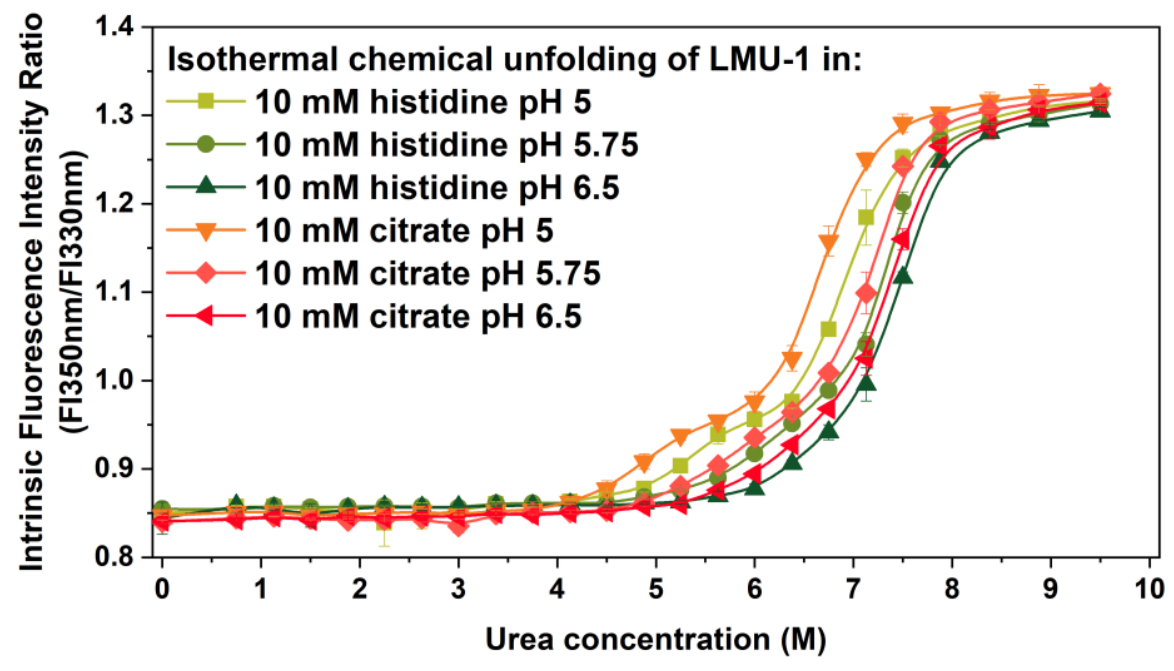

Further, we studied how urea affects the melting temperatures and the aggregation behaviour of the protein with nanoDSF ${ }^{\mathrm{TM}}$. Moderate urea concentrations (up to $4.5 \mathrm{M}$ ) shift the apparent melting temperatures of both proteins to a lower temperature, while higher urea concentrations (6-7.5 $\mathrm{M})$ cause partial protein unfolding at room temperature (Figures 4 and S11). A similar effect of urea on the melting temperatures of a mAb was reported from differential scanning calorimetry experiments ${ }^{61}$. No unfolding upon heating is detected in $9.5 \mathrm{M}$ urea, indicating that the proteins are already unfolded 
at $20^{\circ} \mathrm{C}$ in this urea concentration (Figures 4 and S11). This is in a good agreement with the ICD (Figure 3 and S10) and the near-UV circular dichroism data (see below). The latter observations are consistent among all 24 formulations in this work (data not shown). These results confirm our hypothesis that different urea concentrations (which the protein will inevitably experience during the ReFOLD assay) cause various partially folded protein species in all formulations tested here.

Additionally, we observed that an increasing concentration of urea suppresses the aggregation of the mAbs even at high temperatures (Figures 4 and S11). Similar observations were reported earlier for another antibody ${ }^{61}$. No protein aggregation was detected with the Prometheus NT.48 during the temperature ramp when the protein was in solutions with 5 to $9.5 \mathrm{M}$ urea (Figure 4 and S11), while rapid aggregation was observed around $70-80{ }^{\circ} \mathrm{C}$ in the urea-free LMU-1 and PPI03 formulations. We should note that the nature of the aggregate detection with the Prometheus NT.48 allows us to see only aggregates with a size starting from about $40-50 \mathrm{~nm}$. Therefore, we cannot conclude that the aggregate formation is completely absent in the presence of urea. However, the aggregation growth is greatly inhibited. Furthermore, the isothermal aggregation of the unfolded protein in presence of 9 $\mathrm{M}$ urea was very slow at $25^{\circ} \mathrm{C}$ measured by the change in the apparent hydrodynamic radius of the samples with dynamic light scattering (Figure S12).

Moderate isothermal aggregation of partially unfolded mAbs was already reported in the presence of another denaturant - guanidine hydrochloride ${ }^{50,62}$. This confirms that the aggregation of the proteins unfolded in the presence of urea is suppressed in comparison to aggregation induced by high temperatures. Noteworthy, the moderate aggregation in urea allows a large fraction of the (partially) unfolded protein to remain monomeric and allows the observation of formulation-dependent differences based on the relative monomer yield after refolding. 
Figure 4. Thermal unfolding traces (left) and aggregation during unfolding (right) of LMU-1 in presence of different concentrations of urea. The buffer is $10 \mathrm{mM}$ citrate $\mathrm{pH}$ 6.5. The samples were incubated for $\mathbf{2 4}$ hours in the urea before the measurements. The concentration of LMU-1 in all samples is $1 \mathrm{~g} / \mathrm{L}$.
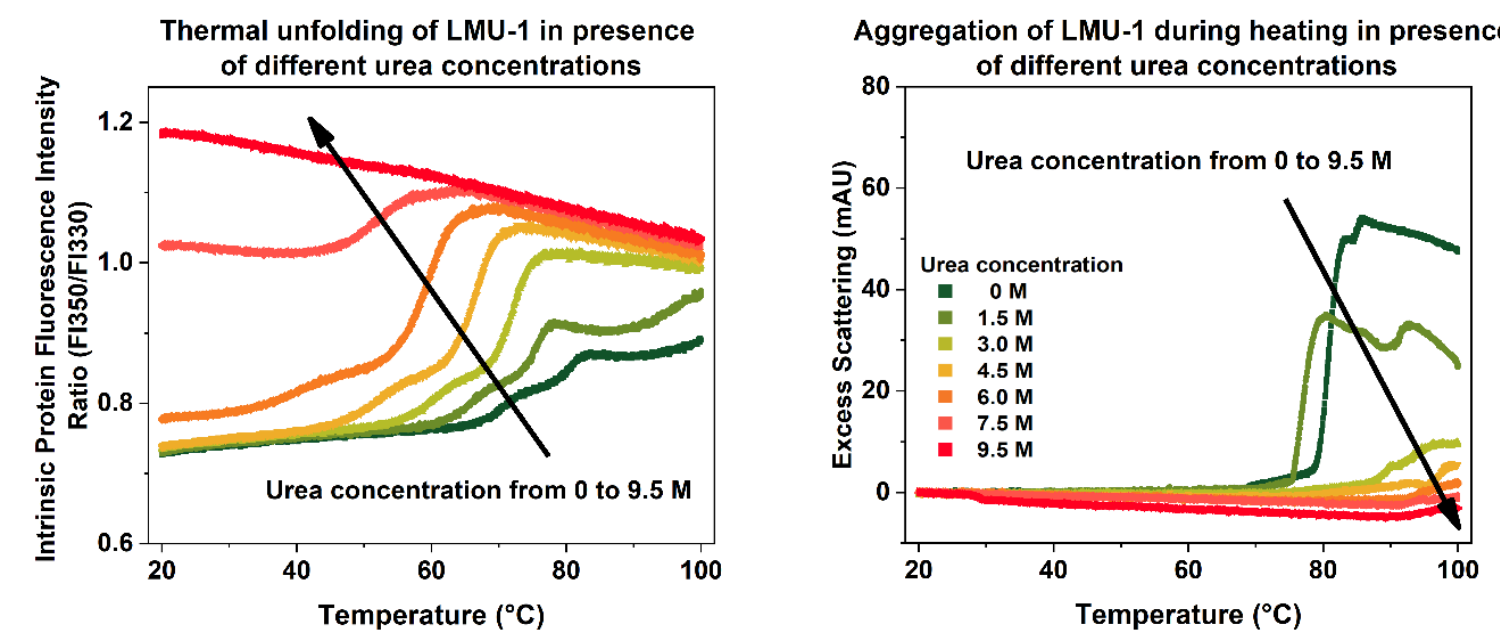

3.4. The samples after isothermal unfolding/refolding have native-like near-UV circular dichroic spectra and increased intermolecular beta sheet content

The near-UV CD spectra of both proteins show typical spectra arising from the signals of the tryptophan, tyrosine, phenylalanine and disulphide bonds having a certain environment in the tertiary

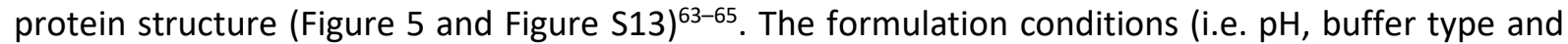
sodium chloride concentration) of the native samples do not affect the characteristics of the spectrapositive peak around $295 \mathrm{~nm}$ and several negative peaks between 280 and $250 \mathrm{~nm}$. The near-UV CD spectra of LMU-1 and PPI03 samples incubated in $9.5 \mathrm{M}$ urea do not contain most of the features of the native samples (Figures 5 and S13). Interestingly, the proteins in the supernatant of the refolded samples from the ReFOLD assay have the typical components of the near-UV CD spectra of the native monomers (Figures 5 and S13). Hawe et al. reported that the near-UV CD spectra of a heat or freezestressed mAbs resemble the native protein ${ }^{66}$. Another group showed that the near-UV spectra of thermally-induced $\mathrm{mAb}$ oligomers resemble the spectra of the native protein ${ }^{67}$. Additionally, the nearUV spectra of a mAb exhibited the same changes during thermal unfolding like the changes we observed during urea-induced isothermal unfolding ${ }^{68}$. 
Figure 5. Near-UV CD spectra of LMU-1 - native (green solid line), unfolded with $10 \mathrm{M}$ urea (yellow dot and dash) and refolded protein (red dot) after the ReFOLD assay was performed with $10 \mathrm{mM}$ histidine pH 5 (A), $10 \mathrm{mM}$ histidine pH 6.5 (B), $10 \mathrm{mM}$ citrate pH 5 (C) and $10 \mathrm{mM}$ citrate pH 6.5 (D). The CD spectra of the refolded samples represent the mixture of protein aggregates and monomer after refolding without any prior fractionation.
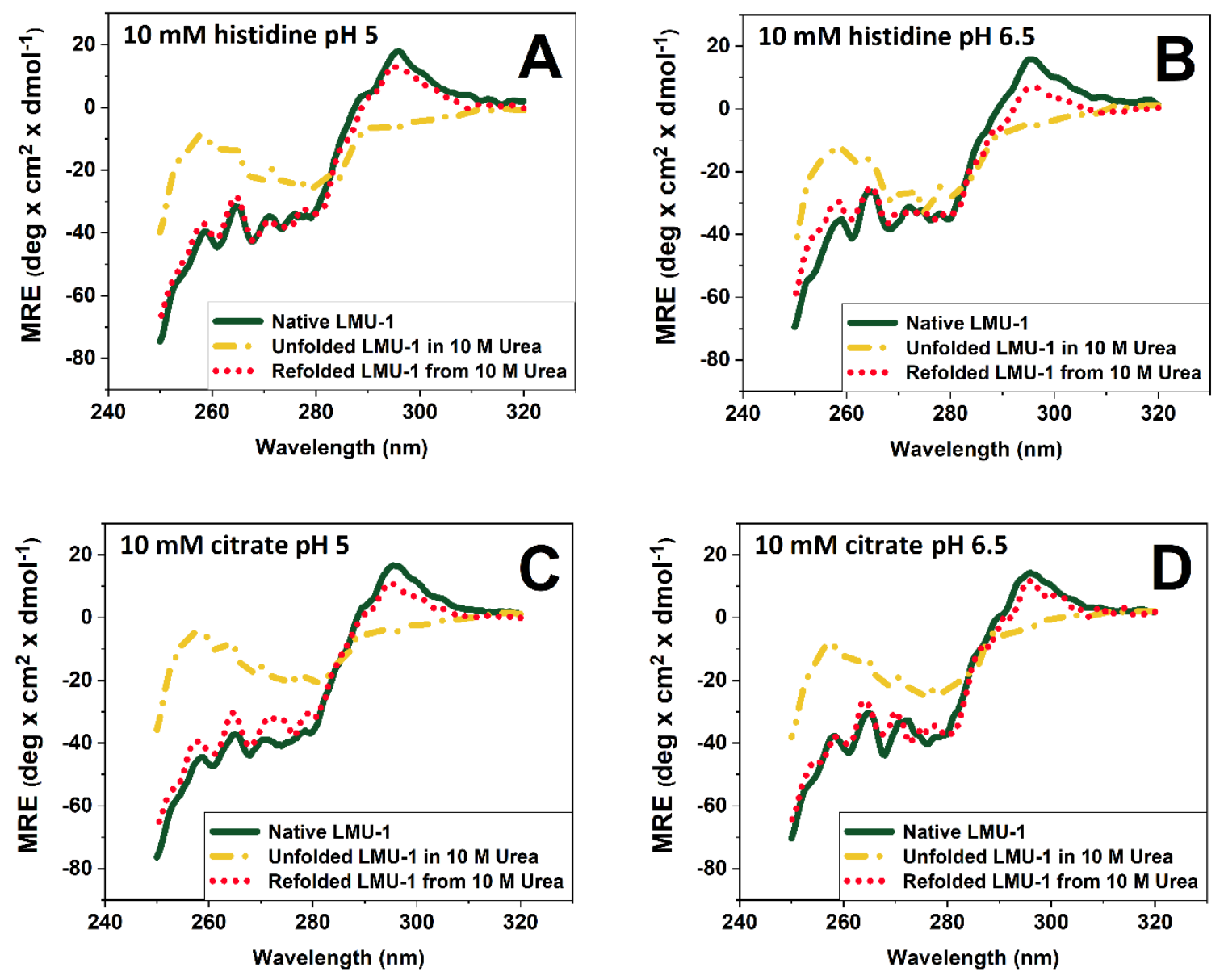

Further, we used FTIR to investigate the secondary protein structure of the native and refolded protein. A minimum around $1638 \mathrm{~cm}^{-1}$ is observed in the Amide I region of the second-derivative FTIR spectra of native LMU-1 samples (Figure 6). This is typical for a native beta-sheet secondary structure and is already reported for monoclonal antibodies ${ }^{69-71}$. The refolded LMU-1 samples show a minimum in the Amide I band which is shifted to $1630 \mathrm{~cm}^{-1}$. The latter is typical when intermolecular beta-sheets are formed ${ }^{69-71}$. The above-mentioned observations were consistent among various formulation conditions we tested in this work. The intermolecular beta-sheets are an often-reported secondary structure of non-native protein aggregates ${ }^{72-74}$. 
Figure 6. FTIR second derivative spectra of native and refolded LMU-1 after the ReFOLD assay was performed with $10 \mathrm{mM}$ histidine pH 5 (A), $10 \mathrm{mM}$ histidine pH 6.5 (B), $10 \mathrm{mM}$ citrate pH 5 (C) and 10 $\mathrm{mM}$ citrate pH 6.5 (D). The CD spectra of the refolded samples represent the mixture of protein aggregates and monomer after refolding without any prior fractionation.
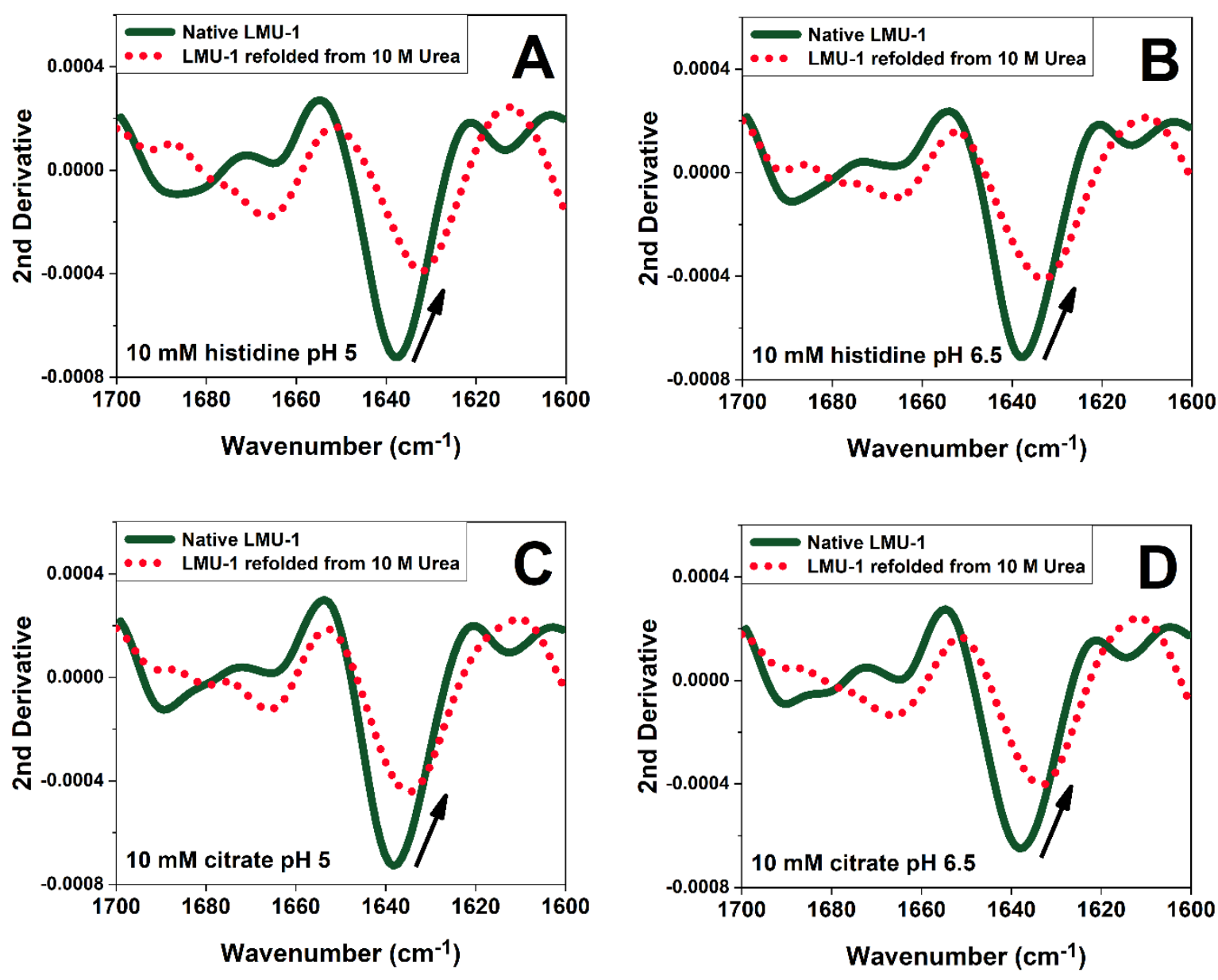


\section{CONCLUSIONS}

This work presents a novel perspective on how to quickly select formulation conditions that will suppress the formation of protein aggregates during long-term storage at $4{ }^{\circ} \mathrm{C}$ and $25^{\circ} \mathrm{C}$. The proposed approach is based on the hypothesis that formulation conditions which suppress the isothermal aggregation of various partially folded species would be formulation conditions that suppress protein aggregation during long-term storage. An isothermal microdialysis-based unfolding/refolding assay, named ReFOLD, is presented and used to assess the relative monomer yield after isothermal unfolding/refolding with $10 \mathrm{M}$ urea of two mAbs, each in 12 different formulation conditions. The relative monomer yield of the proteins in different formulation conditions from the ReFOLD assay shows a very strong to strong correlation with the amount of aggregates formed by the proteins after storage for 12 months at $4{ }^{\circ} \mathrm{C}$ and $25^{\circ} \mathrm{C}$. Other stability-indicating parameters like the apparent protein melting temperatures and aggregation onset temperatures show inverse or weak correlations with the amount of aggregates formed after storage. The refolded protein samples have a native-like near-UV circular dichroic spectra and a peak position in the Amide I band which is typical for aggregated betasheets.

The concept of the ReFOLD assay presented herein opens several directions for future work. First, the ReFOLD assay must be tested with more proteins and on a larger set of formulation conditions to study whether the technique can be used as a universal tool for formulation development. Second, it will be interesting to study in detail the effect of various excipients, i.e. sugars, polyols, amino acids, surfactants, on the relative monomer yield of different proteins and investigate whether excipients that inhibit the aggregation of partially folded species are the excipients that stabilize the proteins during long-term storage. Third, the aggregates and monomers formed after unfolding and refolding in urea can be fractionated and their morphology and structure can be studied more in detail. It would be interesting to see whether the aggregates formed during long-term storage exhibit the same characteristics with the aggregates formed after refolding. Finally, the development of dedicated devices for fully automated and controlled microdialysis with online detection of aggregation and protein unfolding will pave the way for a more comprehensive understanding of the concept behind the ReFOLD assay.

\section{ACKNOWLEDGEMENTS}

This study was funded by a project part of the EU Horizon 2020 Research and Innovation programme under the Marie Skłodowska-Curie grant agreement No 675074.

\section{CONFLICT OF INTERESTS}

None. 


\section{REFERENCES}

(1) Roberts, C. J. Non-Native Protein Aggregation Kinetics; Springer New York: New York, NY, 2007; Vol. 98.

(2) Roberts, C. J.; Das, T. K.; Sahin, E. Predicting Solution Aggregation Rates for Therapeutic Proteins: Approaches and Challenges. Int. J. Pharm. 2011, 418 (2), 318-333.

(3) Manning, M. C.; Chou, D. K.; Murphy, B. M.; Payne, R. W.; Katayama, D. S. Stability of Protein Pharmaceuticals: An Update. Pharm. Res. 2010, 27 (4), 544-575.

(4) Goldberg, D. S.; Bishop, S. M.; Shah, A. U.; Sathish, H. A. Formulation Development of Therapeutic Monoclonal Antibodies Using High-Throughput Fluorescence and Static Light Scattering Techniques: Role of Conformational and Colloidal Stability. J. Pharm. Sci. 2011, 100 (4), 1306-1315.

(5) Jennifer M. Andrews, ¥; Roberts, C. J. A Lumry-Eyring Nucleated Polymerization Model of Protein Aggregation Kinetics: 1. Aggregation with Pre-Equilibrated Unfolding. 2007.

(6) Roberts, C. J. Kinetics of Irreversible Protein Aggregation: Analysis of Extended Lumry-Eyring Models and Implications for Predicting Protein Shelf Life. J. Phys. Chem. B 2003, 107 (5), 1194-1207.

(7) Andrews, J. M.; Roberts, C. J. Non-Native Aggregation of $\alpha$-Chymotrypsinogen Occurs through Nucleation and Growth with Competing Nucleus Sizes and Negative Activation Energies. 2007.

(8) Li, Y.; Roberts, C. J. Protein Aggregation Pathways, Kinetics, and Thermodynamics. In Aggregation of Therapeutic Proteins; John Wiley \& Sons, Inc.: Hoboken, NJ, USA, 2010; pp 63102.

(9) Arosio, P.; Rima, S.; Morbidelli, M. Aggregation Mechanism of an IgG2 and Two IgG1 Monoclonal Antibodies at Low PH: From Oligomers to Larger Aggregates. Pharm. Res. 2013, $30(3), 641-654$.

(10) Moussa, E. M.; Panchal, J. P.; Moorthy, B. S.; Blum, J. S.; Joubert, M. K.; Narhi, L. O.; Topp, E. M. Immunogenicity of Therapeutic Protein Aggregates. J. Pharm. Sci. 2016, 105 (2), 417-430.

(11) Polumuri, S. K.; Haile, L. A.; Ireland, D. D. C.; Verthelyi, D. Aggregates of IVIG or Avastin, but Not HSA, Modify the Response to Model Innate Immune Response Modulating Impurities. Sci. Rep. 2018, 8 (1), 11477.

(12) Ratanji, K. D.; Derrick, J. P.; Dearman, R. J.; Kimber, I. Immunogenicity of Therapeutic Proteins: 
Influence of Aggregation. J. Immunotoxicol. 2014, 11 (2), 99-109.

(13) Kijanka, G.; Bee, J. S.; Korman, S. A.; Wu, Y.; Roskos, L. K.; Schenerman, M. A.; Slütter, B.; Jiskoot, W. Submicron Size Particles of a Murine Monoclonal Antibody Are More Immunogenic Than Soluble Oligomers or Micron Size Particles Upon Subcutaneous Administration in Mice. J. Pharm. Sci. 2018, 107 (11), 2847-2859.

(14) Wang, W.; Kelner, D. N. Correlation of RFVIII Inactivation with Aggregation in Solution. Pharm. Res. 2003, 20 (4), 693-700.

(15) Runkel, L.; Meier, W.; Pepinsky, R. B.; Karpusas, M.; Whitty, A.; Kimball, K.; Brickelmaier, M.; Muldowney, C.; Jones, W.; Goelz, S. E. Structural and Functional Differences Between Glycosylated and Non-Glycosylated Forms of Human Interferon- $\beta$ (IFN- $\beta$ ). Pharm. Res. 1998, 15 (4), 641-649.

(16) ICH, Q5C Quality of Biotechnological Products: Stability Testing of Biotechnological/Biological Products; Geneva, 1995.

(17) ICH , Q6B Specifications: Test Procedures and Acceptance Criteria for Biotechnological/Biological Products; Geneva, 1999.

(18) Spasoff, A.; Bennis, A.; Atkinson, S.; Elliott, C.; Freund, E.; Narhi, L. A Risk- and Science-Based Approach to the Acceptance Sampling Plan Inspection of Protein Parenteral Products. J. Pharm. Sci. 2018, 107 (9), 2306-2309.

(19) Wang, W.; Roberts, C. J. Protein Aggregation - Mechanisms, Detection, and Control. Int. J. Pharm. 2018.

(20) Manning, M. C.; Liu, J.; Li, T.; Holcomb, R. E. Rational Design of Liquid Formulations of Proteins; Academic Press, 2018; pp 1-59.

(21) Goldberg, D. S.; Lewus, R. A.; Esfandiary, R.; Farkas, D. C.; Mody, N.; Day, K. J.; Mallik, P.; Tracka, M. B.; Sealey, S. K.; Samra, H. S. Utility of High Throughput Screening Techniques to Predict Stability of Monoclonal Antibody Formulations During Early Stage Development. J. Pharm. Sci. 2017, 106 (8), 1971-1977.

(22) Capelle, M. A. H.; Gurny, R.; Arvinte, T. A High Throughput Protein Formulation Platform: Case Study of Salmon Calcitonin. Pharm. Res. 2009, 26 (1), 118-128.

(23) Capelle, M. A. H.; Gurny, R.; Arvinte, T. High Throughput Screening of Protein Formulation Stability: Practical Considerations. Eur. J. Pharm. Biopharm. 2007, 65 (2), 131-148. 
(24) Rizzo, J. M.; Shi, S.; Li, Y.; Semple, A.; Esposito, J. J.; Yu, S.; Richardson, D.; Antochshuk, V.; Shameem, M. Application of a High-Throughput Relative Chemical Stability Assay to Screen Therapeutic Protein Formulations by Assessment of Conformational Stability and Correlation to Aggregation Propensity. J. Pharm. Sci. 2015, 104 (5), 1632-1640.

(25) Wanner, R.; Breitsprecher, D.; Duhr, S.; Baaske, P.; Winter, G. Thermo-Optical Protein Characterization for Straightforward Preformulation Development. J. Pharm. Sci. 2017, 106 (10), 2955-2958.

(26) Razinkov, V. I.; Treuheit, M. J.; Becker, G. W. Accelerated Formulation Development of Monoclonal Antibodies (MAbs) and MAb-Based Modalities: Review of Methods and Tools. J. Biomol. Screen. 2015, 1-16.

(27) Menzen, T. A. Temperature-Induced Unfolding, Aggregation, and Interaction of Therapeutic Monoclonal Antibodies. PhD Thesis, LMU Munich 2014.

(28) Malik, K.; Matejtschuk, P.; Thelwell, C.; Burns, C. J. Differential Scanning Fluorimetry: Rapid Screening of Formulations That Promote the Stability of Reference Preparations. J. Pharm. Biomed. Anal. 2013, 77, 163-166.

(29) McClure, S. M.; Ahl, P. L.; Blue, J. T. High Throughput Differential Scanning Fluorimetry (DSF) Formulation Screening with Complementary Dyes to Assess Protein Unfolding and Aggregation in Presence of Surfactants. Pharm. Res. 2018, 35 (4), 81.

(30) Alsenaidy, M. A.; Kim, J. H.; Majumdar, R.; Weis, D. D.; Joshi, S. B.; Tolbert, T. J.; Middaugh, C. R.; Volkin, D. B. High-Throughput Biophysical Analysis and Data Visualization of Conformational Stability of an Igg1 Monoclonal Antibody after Deglycosylation. J. Pharm. Sci. 2013, 102 (11), 3942-3956.

(31) Temel, D. B.; Landsman, P.; Brader, M. L. Orthogonal Methods for Characterizing the Unfolding of Therapeutic Monoclonal Antibodies: Differential Scanning Calorimetry, Isothermal Chemical Denaturation, and Intrinsic Fluorescence with Concomitant Static Light Scattering, 1st ed.; Elsevier Inc., 2016; Vol. 567.

(32) Austerberry, J. I.; Dajani, R.; Panova, S.; Roberts, D.; Golovanov, A. P.; Pluen, A.; van der Walle, C. F.; Uddin, S.; Warwicker, J.; Derrick, J. P.; et al. The Effect of Charge Mutations on the Stability and Aggregation of a Human Single Chain Fv Fragment. Eur. J. Pharm. Biopharm. 2017, 115, 18-30.

(33) Brader, M. L.; Estey, T.; Bai, S.; Alston, R. W.; Lucas, K. K.; Lantz, S.; Landsman, P.; Maloney, K. 
M. Examination of Thermal Unfolding and Aggregation Profiles of a Series of Developable Therapeutic Monoclonal Antibodies. Mol. Pharm. 2015, 12 (4), 1005-1017.

(34) Kheddo, P.; Tracka, M.; Armer, J.; Dearman, R. J.; Uddin, S.; Van Der Walle, C. F.; Golovanov, A. P. The Effect of Arginine Glutamate on the Stability of Monoclonal Antibodies in Solution. Int. J. Pharm. 2014, 473 (1-2), 126-133.

(35) Chakroun, N.; Hilton, D.; Ahmad, S. S.; Platt, G. W.; Dalby, P. A. Mapping the Aggregation Kinetics of a Therapeutic Antibody Fragment. 2015.

(36) Thiagarajan, G.; Semple, A.; James, J. K.; Cheung, J. K.; Shameem, M. A Comparison of Biophysical Characterization Techniques in Predicting Monoclonal Antibody Stability. MAbs 2016, 8 (6), 1088-1097.

(37) Svilenov, H.; Markoja, U.; Winter, G. Isothermal Chemical Denaturation as a Complementary Tool to Overcome Limitations of Thermal Differential Scanning Fluorimetry in Predicting Physical Stability of Protein Formulations. Eur. J. Pharm. Biopharm. 2018, 125, 106-113.

(38) Freire, E.; Schön, A.; Hutchins, B. M.; Brown, R. K. Chemical Denaturation as a Tool in the Formulation Optimization of Biologics. Drug Discov. Today 2013, 18 (19-20), 1007-1013.

(39) Perez-Riba, A.; Itzhaki, L. S. A Method for Rapid High-Throughput Biophysical Analysis of Proteins. Sci. Rep. 2017, 7 (1), 1-6.

(40) Svilenov, H.; Gentiluomo, L.; Friess, W.; Roessner, D.; Winter, G. A New Approach to Study the Physical Stability of Monoclonal Antibody Formulations-Dilution From a Denaturant. J. Pharm. Sci. 2018.

(41) Wafer, L.; Kloczewiak, M.; Polleck, S. M.; Luo, Y. Isothermal Chemical Denaturation of Large Proteins: Path-Dependence and Irreversibility. Anal. Biochem. 2017, 539, 60-69.

(42) Pace, C. N.; Grimsley, G. R.; Scholtz, J. M. Denaturation of Proteins by Urea and Guanidine Hydrochloride. In Protein Folding Handbook; Wiley-VCH Verlag GmbH: Weinheim, Germany; pp 45-69.

(43) Greene, R. F.; Pace, C. N. Urea and Guanidine Hydrochloride Denaturation of Ribonuclease; 1974; Vol. 249.

(44) Ahmad, F.; Bigelow, C. C. Estimation of the Free Energy of Stabilization of Ribonuclease A, Lysozyme, a-Lactalbumin, and Myoglobin*. J. Biol. Chem. 1982, 257 (21), 12935-12938.

(45) Nick Pace, C.; Laurents, D. V; Thomson, J. A. PH Dependence of the Urea and Guanidine 
Hydrochloride Denaturation of Ribonuclease A and Ribonuclease T1; Wagner, P, 2564; Vol. 29.

(46) Niklasson, M.; Andresen, C.; Helander, S.; Roth, M. G. L.; Zimdahl Kahlin, A.; Lindqvist Appell, M.; Mårtensson, L.-G.; Lundström, P. Robust and Convenient Analysis of Protein Thermal and Chemical Stability. Protein Sci. 2015, 24 (12), 2055-2062.

(47) Schön, A.; Clarkson, B. R.; Siles, R.; Ross, P.; Brown, R. K.; Freire, E. Denatured State Aggregation Parameters Derived from Concentration Dependence of Protein Stability. Anal. Biochem. 2015, 488, 45-50.

(48) Clarkson, B. R.; Schön, A.; Freire, E. Conformational Stability and Self-Association Equilibrium in Biologics. Drug Discov. Today 2016, 21 (2), 342-347.

(49) Guo, J.; Kumar, S.; Chipley, M.; Marcq, O.; Gupta, D.; Jin, Z.; Tomar, D. S.; Swabowski, C.; Smith, J.; Starkey, J. A.; et al. Characterization and Higher-Order Structure Assessment of an Interchain Cysteine-Based ADC: Impact of Drug Loading and Distribution on the Mechanism of Aggregation. Bioconjug. Chem. 2016, 27 (3), 604-615.

(50) Rowe, J. B.; Flynn, R. P.; Wooten, H. R.; Noufer, H. A.; Cancel, R. A.; Zhang, J.; Subramony, J. A.; Pechenov, S.; Wang, Y. Submicron Aggregation of Chemically Denatured Monoclonal Antibody. Mol. Pharm. 2018, 15 (10), 4710-4721.

(51) Yamaguchi, S.; Yamamoto, E.; Mannen, T.; Nagamune, T. Protein Refolding Using Chemical Refolding Additives. Biotechnol. J. 2013, 8 (1), 17-31.

(52) De Bernardez Clark, E. Refolding of Recombinant Proteins. Curr. Opin. Biotechnol. 1998, 9 (2), 157-163.

(53) Ho, J. G. S.; Middelberg, A. P. J. Estimating the Potential Refolding Yield of Recombinant Proteins Expressed as Inclusion Bodies. Biotechnol. Bioeng. 2004, 87 (5), 584-592.

(54) Yasuda, M.; Murakami, Y.; Sowa, A.; Ogino, H.; Ishikawa, H. Effect of Additives on Refolding of a Denatured Protein. Biotechnol. Prog. 1998, 14 (4), 601-606.

(55) Arakawa, T.; Ejima, D. Refolding Technologies for Antibody Fragments. Antibodies 2014, 3 (2), 232-241.

(56) Pramanick, S.; Singodia, D.; Chandel, V. Excipient Selection In Parenteral Formulation Development; 2013; Vol. 45.

(57) Breitsprecher, D.; Glücklich, N.; Hawe, A.; Menzen, T. Thermal Unfolding of Antibodies Comparison of NanoDSF and MDSC for Thermal Stability Assessment during 
Biopharmaceutical Formulation Development. Appl. Note NT-PR-006, NanoTemper Technol. GmbH 2016.

(58) Breitsprecher, D.; Linke, P.; Schulze, A.; Söltl, F.; Glücklich, N.; Hawe, A.; Menzen, T.; Garidel, P.; Blech, M. Automated NanoDSF for High-Throughput Thermal , Colloidal and Chemical Stability Screenings. Prometh. NT.Plex Prod. information, NanoTemper Technol. GmbH.

(59) Towsend, R.; Kumosisski, T. F.; Timasheff, S. N. The Circular Dichroism of Variants of PLactoglobulin; 1967; Vol. 242.

(60) Savitzky, A.; E, M. J. Smoothing and Differentiation of Data by Simplified Least Squares Procedures; 1951; Vol. 40.

(61) Nemergut, M.; Zoldak, G.; Schaefer, J. V; Kast, F.; Miskovsky, P.; Plückthun, A.; Sedlak, E. Analysis of IgG Kinetic Stability by Differential Scanning Calorimetry, Probe Fluorescence and Light Scattering. 2017.

(62) Mehta, S. B.; Bee, J. S.; Randolph, T. W.; Carpenter, J. F. Partial Unfolding of a Monoclonal Antibody: Role of a Single Domain in Driving Protein Aggregation. Biochemistry 2014, 53 (20), 3367-3377.

(63) Freskgard, P.-O.; Martensson, L.-G.; Jonasson, P.; Jonsson, B.-H.; Carlsson, U. Assignment of the Contribution of the Tryptophan Residues to the Circular Dichroism Spectrum of Human Carbonic Anhydrase II; 1994; Vol. 33.

(64) Woody, A.-Y. M.; Woody, R. W. Individual Tyrosine Side-Chain Contributions to Circular Dichroism of Ribonuclease. Biopolymers 2003, 72 (6), 500-513.

(65) Sreerama, N.; Manning, M. C.; Powers, M. E.; Zhang, J.-X.; Goldenberg, D. P.; Woody, R. W. Tyrosine, Phenylalanine, and Disulfide Contributions to the Circular Dichroism of Proteins: Circular Dichroism Spectra of Wild-Type and Mutant Bovine Pancreatic Trypsin Inhibitor †. 1999.

(66) Hawe, A.; Kasper, J. C.; Friess, W.; Jiskoot, W. Structural Properties of Monoclonal Antibody Aggregates Induced by Freeze-thawing and Thermal Stress. Eur. J. Pharm. Sci. 2009, 38 (2), 79-87.

(67) Franey, H.; Brych, S. R.; Kolvenbach, C. G.; Rajan, R. S. Increased Aggregation Propensity of IgG2 Subclass over IgG1: Role of Conformational Changes and Covalent Character in Isolated Aggregates. Protein Sci. 2010, 19 (9), 1601-1615.

(68) Vermeer, a W.; Norde, W. The Thermal Stability of Immunoglobulin: Unfolding and 
Aggregation of a Multi-Domain Protein. Biophys. J. 2000, 78 (1), 394-404.

(69) Mahler, H.-C.; Jiskoot, W. Analysis of Aggregates and Particles in Protein Pharmaceuticals; John Wiley \& Sons, 2012.

(70) Apicella, A.; Soncini, M.; Deriu, M. A.; Natalello, A.; Bonanomi, M.; Dellasega, D.; Tortora, P.; Regonesi, M. E.; Casari, C. S. A Hydrophobic Gold Surface Triggers Misfolding and Aggregation of the Amyloidogenic Josephin Domain in Monomeric Form, While Leaving the Oligomers Unaffected. PLoS One 2013, 8 (3), e58794.

(71) Telikepalli, S. N.; Kumru, O. S.; Kalonia, C.; Esfandiary, R.; Joshi, S. B.; Middaugh, C. R.; Volkin, D. B. Structural Characterization of IgG1 MAb Aggregates and Particles Generated Under Various Stress Conditions. J. Pharm. Sci. 2014, 103 (3), 796-809.

(72) Weiss, W. F.; Hodgdon, T. K.; Kaler, E. W.; Lenhoff, A. M.; Roberts, C. J. Nonnative Protein Polymers: Structure, Morphology, and Relation to Nucleation and Growth. Biophys. J. 2007, 93 (12), 4392-4403.

(73) Arosio, P.; Barolo, G.; Müller-Späth, T.; Wu, H.; Morbidelli, M. Aggregation Stability of a Monoclonal Antibody During Downstream Processing.

(74) Eisenberg, D.; Nelson, R.; Sawaya, M. R.; Balbirnie, M.; Sambashivan, S.; Ivanova, M. I.; Madsen, A. $\varnothing$.; Riekel, C. The Structural Biology of Protein Aggregation Diseases: Fundamental Questions and Some Answers. 2006. 


\title{
Supplementary data
}

to

\section{"The ReFOLD assay for protein formulation studies and prediction of protein aggregation during long-term storage"}

\author{
Hristo Svilenov†, Gerhard Winter \\ Department of Pharmacy, Pharmaceutical Technology and Biopharmaceutics, Ludwig-Maximilians- \\ University, Butenandtstrasse 5-13, Munich D-81377, Germany \\ †Corresponding author: hrisph@cup.uni-muenchen.de
}

\section{Determination of aggregation onset temperature with dynamic light scattering}

$25 \mu \mathrm{L}$ of protein solution was filled in a 384 well plate (Corning) and the plate was centrifuged at 2200 rpm for 2 minutes using a Heraeus Megafuge 40 centrifuge equipped with an M-20 well plate rotor (Thermo Fisher Scientific, Wilmington, USA). Next, a drop of silicone oil was used to seal each well and the samples were centrifuged again at $2200 \mathrm{rpm}$ for 2 minutes. Unless otherwise stated, the well plate was placed in a Dyna Pro DLS plate reader (Wyatt Technology, Santa Barbara, USA) and a temperature ramp of $0.25{ }^{\circ} \mathrm{C} / \mathrm{min}$ was applied from 25 to $80^{\circ} \mathrm{C}$. During the temperature ramp, the samples were measured with 3 acquisitions of 3 seconds. The autocorrelation function (ACF) of each sample was calculated from the fluctuation of the light scattering intensity using the Dynamics V7.8 software. Cumulant analysis was performed with the same software to derive the apparent coefficient of selfdiffusion (D) and the polydispersity index (PDI). Next, the apparent protein hydrodynamic radius from DLS $\left(R_{h}\right)$ was calculated using the Stokes-Einstein equation. The aggregation onset temperature (Ton) from the increase in the $R_{h}$ from DLS was determined using the Dynamics V7.8 software. All measurements were performed in triplicates. 
Table S1. Relative Monomer Yield (RMY) of LMU-1 formulations after the ReFOLD assay and the relative content of high molecular weight species after long term storage of the respective LMU-1 formulations

\begin{tabular}{|c|c|c|c|c|c|c|c|c|c|c|c|c|}
\hline $\begin{array}{c}\text { Formulation } \\
\text { number }\end{array}$ & $\begin{array}{l}\text { Protein } \\
\text { conc. }\end{array}$ & Buffer & $\mathrm{pH}$ & \multicolumn{3}{|c|}{$\begin{array}{l}\text { RMY after refolding } \\
\text { from } 10 \mathrm{M} \text { urea }\end{array}$} & \multicolumn{3}{|c|}{$\begin{array}{l}\% \text { HMW after } 12 \\
\text { months at } 25^{\circ} \mathrm{C}\end{array}$} & \multicolumn{3}{|c|}{$\begin{array}{c}\% \mathrm{HMW} \text { after } 12 \\
\text { months at } 4{ }^{\circ} \mathrm{C}\end{array}$} \\
\hline 1 & 10 & histidine & 5 & 0.401 & 0.387 & 0.372 & 0.21 & 0.23 & 0.18 & 0.11 & 0.14 & 0.21 \\
\hline 2 & 10 & histidine & 5.75 & 0.378 & 0.365 & 0.390 & 0.15 & 0.18 & 0.17 & 0.25 & 0.17 & 0.17 \\
\hline 3 & 10 & histidine & 6.5 & 0.269 & 0.272 & 0.265 & 0.38 & 0.55 & 0.41 & 0.27 & 0.21 & 0.37 \\
\hline 4 & 10 & citrate & 5 & 0.239 & 0.243 & 0.240 & 0.47 & 0.53 & 0.53 & 0.34 & 0.30 & 0.30 \\
\hline 5 & 10 & citrate & 5.75 & 0.17 & 0.164 & 0.169 & 0.79 & 0.66 & 0.72 & 0.32 & 0.43 & 0.34 \\
\hline 6 & 10 & citrate & 6.5 & 0.153 & 0.166 & 0.157 & 0.91 & 0.85 & 1.06 & 0.57 & 0.65 & 0.60 \\
\hline 7 & 50 & histidine & 5 & 0.098 & 0.097 & 0.092 & 0.67 & 0.72 & 0.72 & 0.43 & 0.47 & 0.51 \\
\hline 8 & 50 & histidine & 5.75 & 0.082 & 0.079 & 0.088 & 0.87 & 0.89 & 0.83 & 0.54 & 0.67 & 0.55 \\
\hline 9 & 50 & histidine & 6.5 & 0.003 & 0.009 & 0.002 & 1.66 & 1.61 & 1.55 & 0.90 & 0.93 & 0.94 \\
\hline 10 & 50 & citrate & 5 & 0.065 & 0.074 & 0.074 & 0.93 & 0.93 & 1.07 & 0.39 & 0.51 & 0.41 \\
\hline 11 & 50 & citrate & 5.75 & 0.036 & 0.030 & 0.039 & 1.08 & 1.13 & 1.24 & 0.57 & 0.61 & 0.60 \\
\hline 12 & 50 & citrate & 6.5 & 0.022 & 0.023 & 0.017 & 1.68 & 1.73 & 1.86 & 1.08 & 1.02 & 0.93 \\
\hline
\end{tabular}


Table S2. Relative Monomer Yield (RMY) of PPI03 formulations after the ReFOLD assay and the relative content of high molecular weight species, i.e. protein aggregates, after long term storage* of the respective PPI03 formulations. The concentration of PPI03 is $5 \mathrm{~g} / \mathrm{L}$ in all 12 formulations.

\begin{tabular}{|c|c|c|c|c|c|c|c|c|c|c|c|c|}
\hline $\begin{array}{c}\text { Form. } \\
\text { number }\end{array}$ & Buffer & $\mathrm{pH}$ & $\mathrm{NaCl}$ & \multicolumn{2}{c|}{$\begin{array}{r}\text { RMY after refolding } \\
\text { from } 10 \mathrm{M} \text { urea }\end{array}$} & \multicolumn{2}{c|}{$\begin{array}{c}\text { \% HMW after } 12 \\
\text { months at } 25^{\circ} \mathrm{C}\end{array}$} & \multicolumn{3}{c|}{$\begin{array}{c}\text { \% HMW after } 12 \\
\text { months at } 4{ }^{\circ} \mathrm{C}\end{array}$} \\
\hline 1 & histidine & 5 & $\mathrm{No}$ & 0.519 & 0.535 & 0.553 & 0.11 & 0.11 & 0.14 & 0.16 & 0.16 & 0.14 \\
\hline 2 & histidine & 5.75 & $\mathrm{No}$ & 0.47 & 0.47 & 0.495 & 0.15 & 0.13 & 0.13 & 0.15 & 0.13 & 0.14 \\
\hline 3 & histidine & 6.5 & $\mathrm{No}$ & 0.514 & 0.474 & 0.461 & 0.18 & 0.18 & 0.18 & 0.14 & 0.16 & 0.16 \\
\hline 4 & histidine & 5 & $70 \mathrm{mM}$ & 0.352 & 0.359 & 0.355 & 0.22 & 0.24 & 0.26 & 0.17 & 0.16 & 0.17 \\
\hline 5 & histidine & 5.75 & $70 \mathrm{mM}$ & 0.334 & 0.338 & 0.335 & 0.23 & 0.24 & 0.24 & 0.17 & 0.17 & 0.17 \\
\hline 6 & histidine & 6.5 & $70 \mathrm{mM}$ & 0.336 & 0.305 & 0.317 & 0.41 & 0.46 & 0.43 & 0.24 & 0.26 & 0.24 \\
\hline 7 & citrate & 5 & $\mathrm{No}$ & 0.418 & 0.417 & 0.397 & 0.5 & 0.44 & 0.43 & 0.24 & 0.23 & 0.22 \\
\hline 8 & citrate & 5.75 & $\mathrm{No}$ & 0.303 & 0.294 & 0.296 & 0.55 & 0.48 & 0.46 & 0.31 & 0.33 & 0.32 \\
\hline 9 & citrate & 6.5 & $\mathrm{No}$ & 0.255 & 0.284 & 0.285 & 0.65 & 0.67 & 0.64 & 0.56 & 0.54 & 0.54 \\
\hline 10 & citrate & 5 & $70 \mathrm{mM}$ & 0.431 & 0.399 & 0.421 & 0.5 & 0.45 & 0.48 & 0.24 & 0.23 & 0.22 \\
\hline 11 & citrate & 5.75 & $70 \mathrm{mM}$ & 0.364 & 0.339 & 0.323 & 0.41 & 0.44 & 0.44 & 0.29 & 0.3 & 0.29 \\
\hline 12 & citrate & 6.5 & $70 \mathrm{mM}$ & 0.337 & 0.346 & 0.353 & 0.63 & 0.63 & 0.6 & 0.55 & 0.55 & 0.56 \\
\hline
\end{tabular}

*The relative content of high molecular weight species of PPI03 after storage was measured with the same SEC method described in materials and methods. However, the elution of the protein was detected with a Dionex RF2000 fluorescence detector (Thermo Fisher, Dreieich, Germany) using the following parameters - excitation at $280 \mathrm{~nm}$, emission at $343 \mathrm{~nm}$, gain 4.0 and medium sensitivity. There is a linear correlation $\left(R^{2}>0.98\right)$ between the relative area of high molecular weight species of PPI03 detected by UV absorption at $280 \mathrm{~nm}$ and by intrinsic fluorescence (data not shown). However, in the case of PPI03 many of the samples contained less than $0.2 \%$ aggregates and the use of the fluorescence detector provided a better signal-to-noise ratio compared to the UV detector. 
Table S3. Monomer recovery of LMU-1 after 12 months of storage at $25{ }^{\circ} \mathrm{C}$ and $4{ }^{\circ} \mathrm{C}$. The monomer recovery was calculated by dividing the area of the monomer peak in the SEC chromatograms after 12 months of storage by the area of the monomer peak at the beginning of the stability study, and finally multiplying this value by 100 . A value of $100 \%$ therefore indicates that the same monomer area was fond after storage, while a value lower than $100 \%$ indicates that the area of the monomer was smaller.

\begin{tabular}{|c|c|c|c|c|c|c|c|}
\hline \multirow[t]{2}{*}{$\begin{array}{c}\text { Formulation } \\
\text { number }\end{array}$} & \multirow[t]{2}{*}{$\begin{array}{c}\text { Protein } \\
\text { conc. } \\
{[\mathrm{g} / \mathrm{L}]}\end{array}$} & \multirow[t]{2}{*}{ Buffer } & \multirow[t]{2}{*}{$\mathrm{pH}$} & \multicolumn{2}{|c|}{$\begin{array}{c}\text { SEC monomer recovery } \\
\text { (\%) after } 12 \text { months at } \\
25^{\circ} \mathrm{C}\end{array}$} & \multicolumn{2}{|c|}{$\begin{array}{c}\text { SEC monomer } \\
\text { recovery (\%) after } 12 \\
\text { months at } 4{ }^{\circ} \mathrm{C}\end{array}$} \\
\hline & & & & Mean & StDev & Mean & StDev \\
\hline 1 & 10 & histidine & 5 & 99.96 & 0.05 & 100.54 & 0.22 \\
\hline 2 & 10 & histidine & 5.75 & 100.91 & 1.46 & 100.24 & 0.08 \\
\hline 3 & 10 & histidine & 6.5 & 100.43 & 1.14 & 99.99 & 0.14 \\
\hline 4 & 10 & citrate & 5 & 101.23 & 0.65 & 101.18 & 0.20 \\
\hline 5 & 10 & citrate & 5.75 & 100.15 & 0.66 & 100.13 & 0.38 \\
\hline 6 & 10 & citrate & 6.5 & 99.94 & 0.17 & 100.02 & 0.18 \\
\hline 7 & 50 & histidine & 5 & 96.15 & 1.17 & 99.50 & 0.54 \\
\hline 8 & 50 & histidine & 5.75 & 96.34 & 0.41 & 99.56 & 0.25 \\
\hline 9 & 50 & histidine & 6.5 & 95.48 & 1.20 & 99.06 & 0.26 \\
\hline 10 & 50 & citrate & 5 & 95.29 & 1.05 & 97.94 & 0.24 \\
\hline 11 & 50 & citrate & 5.75 & 95.38 & 0.51 & 98.36 & 0.41 \\
\hline 12 & 50 & citrate & 6.5 & 95.36 & 0.22 & 97.68 & 0.77 \\
\hline
\end{tabular}

Table S4. Monomer recovery of PPI03 after 12 months of storage at $25{ }^{\circ} \mathrm{C}$ and $4{ }^{\circ} \mathrm{C}$. The monomer recovery was calculated by dividing the area of the monomer peak in the SEC chromatograms after 12 months of storage by the area of the monomer peak at the beginning of the stability study, and finally multiplying this value by 100 . A value of $100 \%$ therefore indicates that the same monomer area was fond after storage, while a value lower than $100 \%$ indicates that the area of the monomer was smaller.

\begin{tabular}{|c|c|c|c|c|c|c|c|}
\hline \multirow[t]{2}{*}{$\begin{array}{c}\text { Formulation } \\
\text { number }\end{array}$} & \multirow[t]{2}{*}{ Buffer } & \multirow[t]{2}{*}{$\mathrm{pH}$} & \multirow[t]{2}{*}{$\mathrm{NaCl}$} & \multicolumn{2}{|c|}{$\begin{array}{l}\text { SEC monomer } \\
\text { recovery (\%) after } \\
12 \text { months at } 25^{\circ} \mathrm{C}\end{array}$} & \multicolumn{2}{|c|}{$\begin{array}{l}\text { SEC monomer recovery } \\
\text { (\%) after } \\
12 \text { months at } 4{ }^{\circ} \mathrm{C}\end{array}$} \\
\hline & & & & Mean & StDev & Mean & StDev \\
\hline 1 & histidine & 5 & No & 99.57 & 0.57 & 100.15 & 0.36 \\
\hline 2 & histidine & 5.75 & No & 98.87 & 0.37 & 99.48 & 0.20 \\
\hline 3 & histidine & 6.5 & No & 99.14 & 0.10 & 98.97 & 0.40 \\
\hline 4 & citrate & 5 & $70 \mathrm{mM}$ & 98.39 & 0.08 & 98.88 & 0.24 \\
\hline 5 & citrate & 5.75 & $70 \mathrm{mM}$ & 99.21 & 1.50 & 98.77 & 0.45 \\
\hline 6 & citrate & 6.5 & $70 \mathrm{mM}$ & 98.80 & 0.34 & 98.99 & 0.18 \\
\hline 7 & histidine & 5 & No & 96.91 & 0.34 & 98.67 & 0.36 \\
\hline 8 & histidine & 5.75 & No & 96.86 & 0.35 & 97.82 & 0.37 \\
\hline 9 & histidine & 6.5 & No & 98.11 & 0.60 & 98.47 & 0.35 \\
\hline 10 & citrate & 5 & $70 \mathrm{mM}$ & 96.78 & 0.45 & 98.19 & 0.62 \\
\hline 11 & citrate & 5.75 & $70 \mathrm{mM}$ & 96.76 & 0.92 & 96.86 & 0.55 \\
\hline 12 & citrate & 6.5 & $70 \mathrm{mM}$ & 98.32 & 0.53 & 98.67 & 0.79 \\
\hline
\end{tabular}


Figure S1. Representative chromatograms of LMU-1 and PPI03 obtained with the size-exclusion chromatography method used during the long-term stability studies. The area of high molecular weight (HMW) species is integrated between 5 and 15.1 minutes retention time. The protein monomer is integrated between 15.1 and 22 minutes.
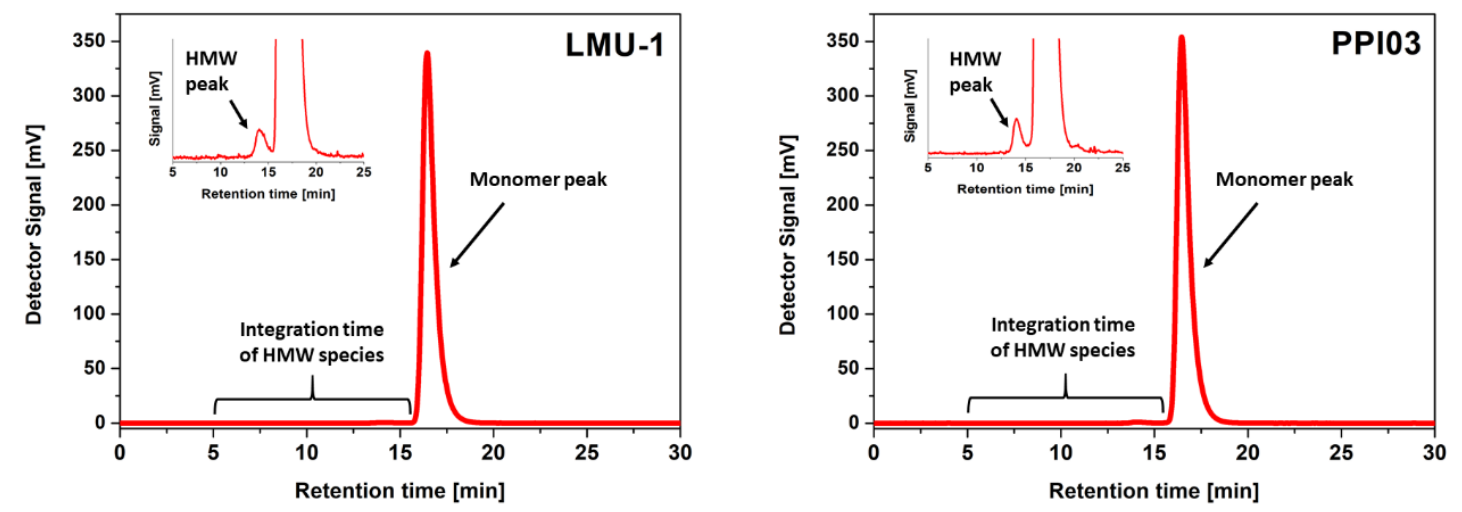

The \% of high molecular weight (HMW) species after long-term storage is calculated using the following equation: HMW Species $(\%)=(($ Area of $\mathrm{HMW}) /($ Area of all peaks $)) * 100$ 
Figure S2. Subvisible particles in the LMU-1 and PPI03 formulations after 12 months of storage at $25^{\circ} \mathrm{C}$. The numbers represent cumulative particles larger than $2 \mu \mathrm{m}$ in $1 \mathrm{~mL}$. After 12 months of storage at $4{ }^{\circ} \mathrm{C}$, all formulations contained less than 5000 particles $\geq 2 \mu \mathrm{m}$ per $\mathrm{mL}$ (data not shown). The measurements were performed with a FlowCAM ${ }^{\circledR} 8100$ (Fluid Imaging Technologies, Inc., Scarborough, ME, USA). The system was equipped with a 10x magnification cell ( $81 \mu \mathrm{m} \times 700 \mu \mathrm{m})$. Before each measurement, the cleanliness of the cell was checked visually. $200 \mu \mathrm{L}$ of sample were used for the analysis and the images are collected with a flow rate of $0.15 \mathrm{~mL} / \mathrm{min}$, auto image frame rate of 29 frames/second and a sampling time of 74 seconds. The following settings were used for particle identification - $3 \mu \mathrm{m}$ distance to the nearest neighbour, particle segmentation thresholds of 13 and 10 for the dark and light pixels respectively. The particle size was reported as the equivalent spherical diameter (ESD). The VisualSpreadsheet ${ }^{\circledR} 4.7 .6$ software was used for data collection and evaluation.
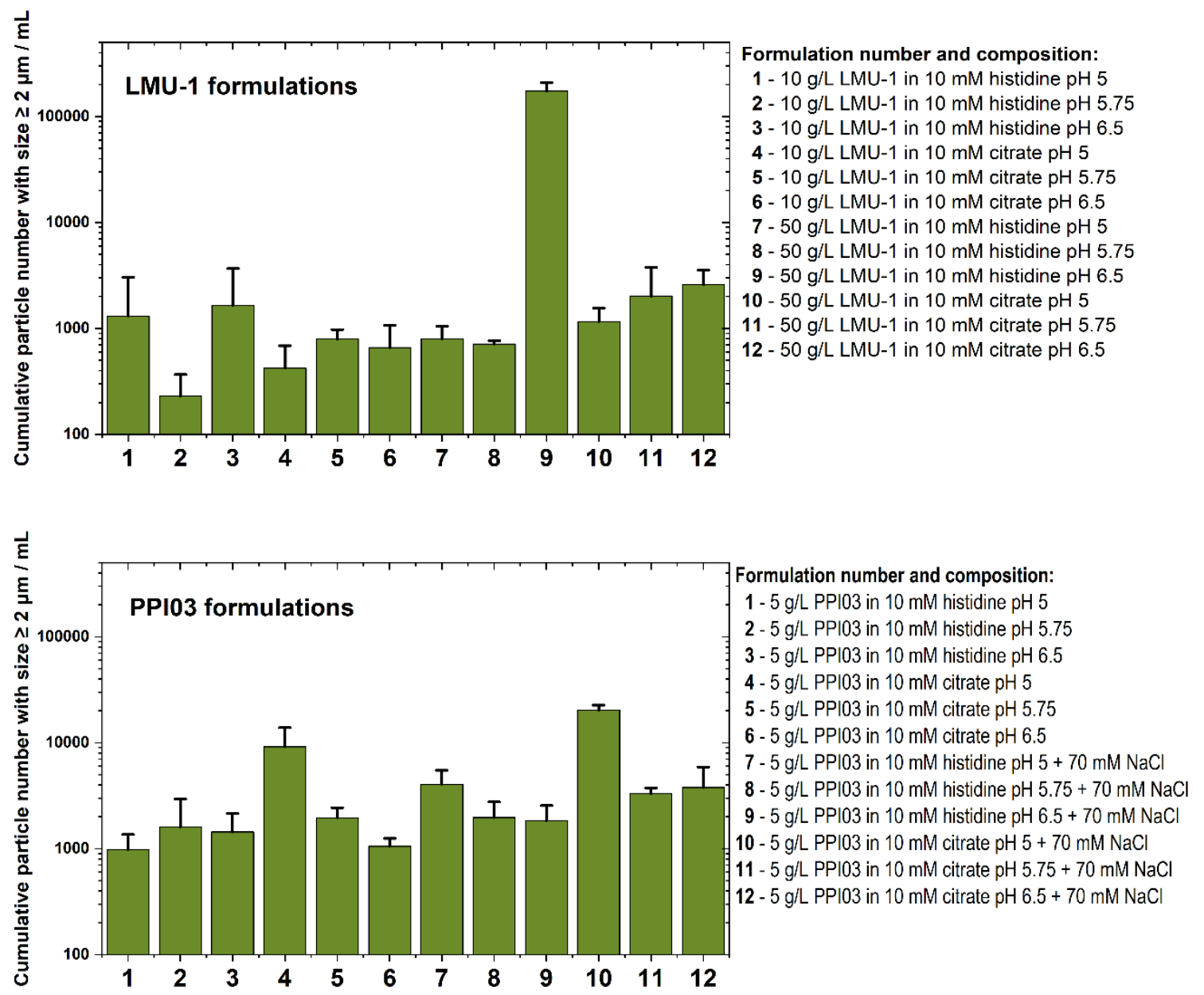
Figure S3. Correlation between the first melting temperature $T_{m 1}$ of $L M U-1$ and the relative content of high molecular weight species detected by size exclusion chromatography after 12 months of storage at $25^{\circ} \mathrm{C}$ (left) and at $4{ }^{\circ} \mathrm{C}$ (right). The value of each replicate is shown on the graph. The solid red line is linear fit of the data, the dark red zone represents the $95 \%$ confidence interval of the fit and the light red zone the $95 \%$ prediction interval.
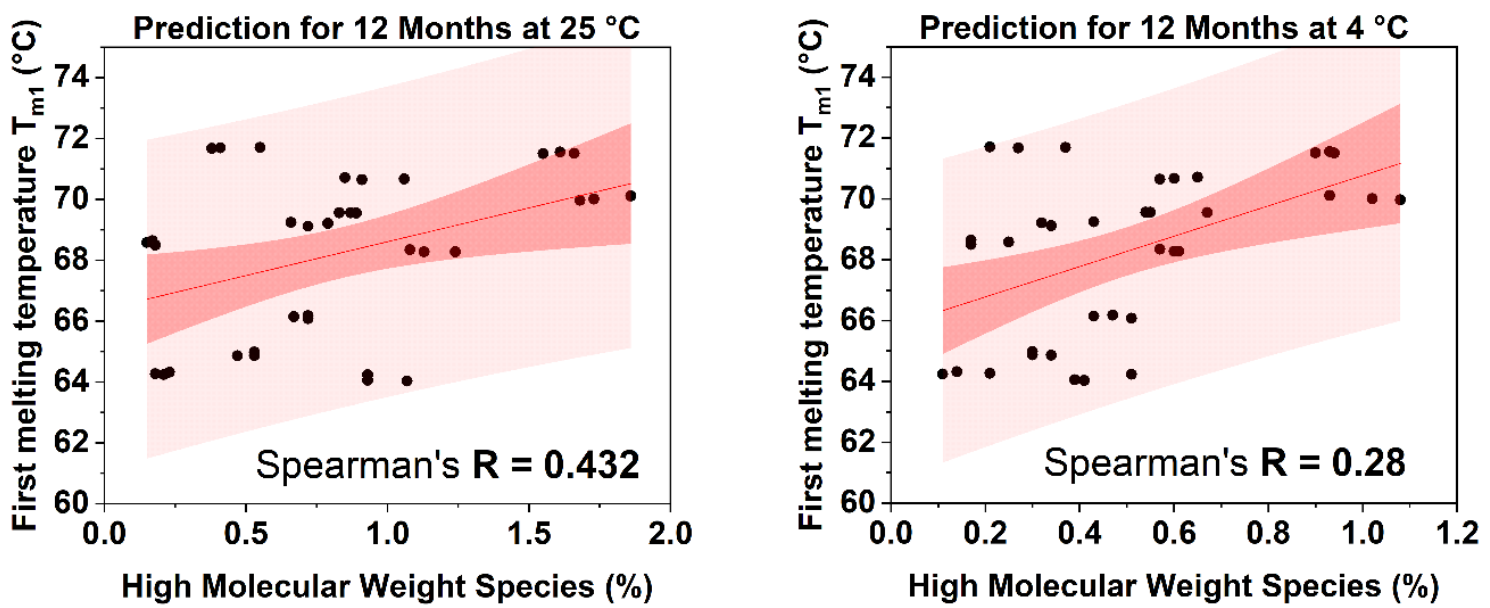

Figure S4. Correlation between the second melting temperature $T_{m 2}$ of $L M U-1$ and the relative content of high molecular weight species detected by size exclusion chromatography after 12 months of storage at $25^{\circ} \mathrm{C}$ (left) and at $4{ }^{\circ} \mathrm{C}$ (right). The value of each replicate is shown on the graph. The solid red line is linear fit of the data, the dark red zone represents the $95 \%$ confidence interval of the fit and the light red zone the $95 \%$ prediction interval.
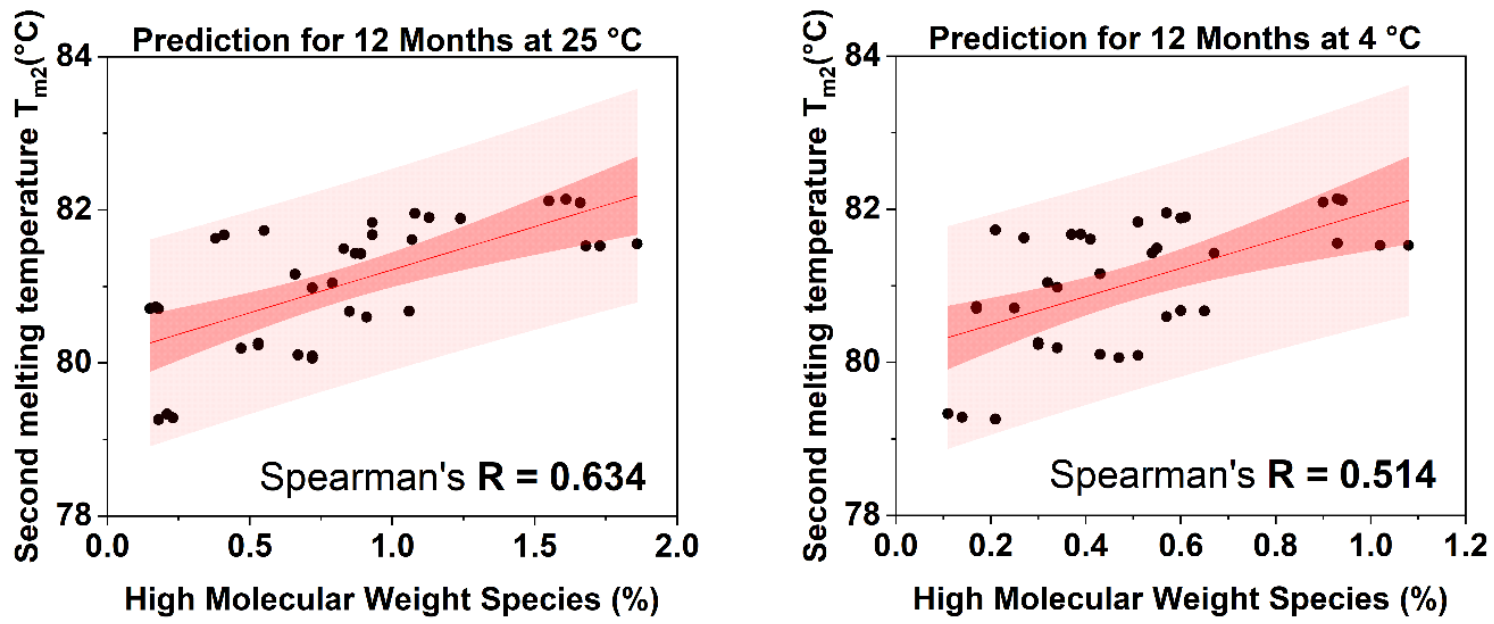
Figure S5. Correlation between the aggregation onset temperature from DLS of LMU-1 and the relative content of high molecular weight species detected by size exclusion chromatography after 12 months of storage at $25^{\circ} \mathrm{C}$ (left) and at $4{ }^{\circ} \mathrm{C}$ (right). The value of each replicate is shown on the graph. The solid red line is linear fit of the data, the dark red zone represents the $95 \%$ confidence interval of the fit and the light red zone the $95 \%$ prediction interval.
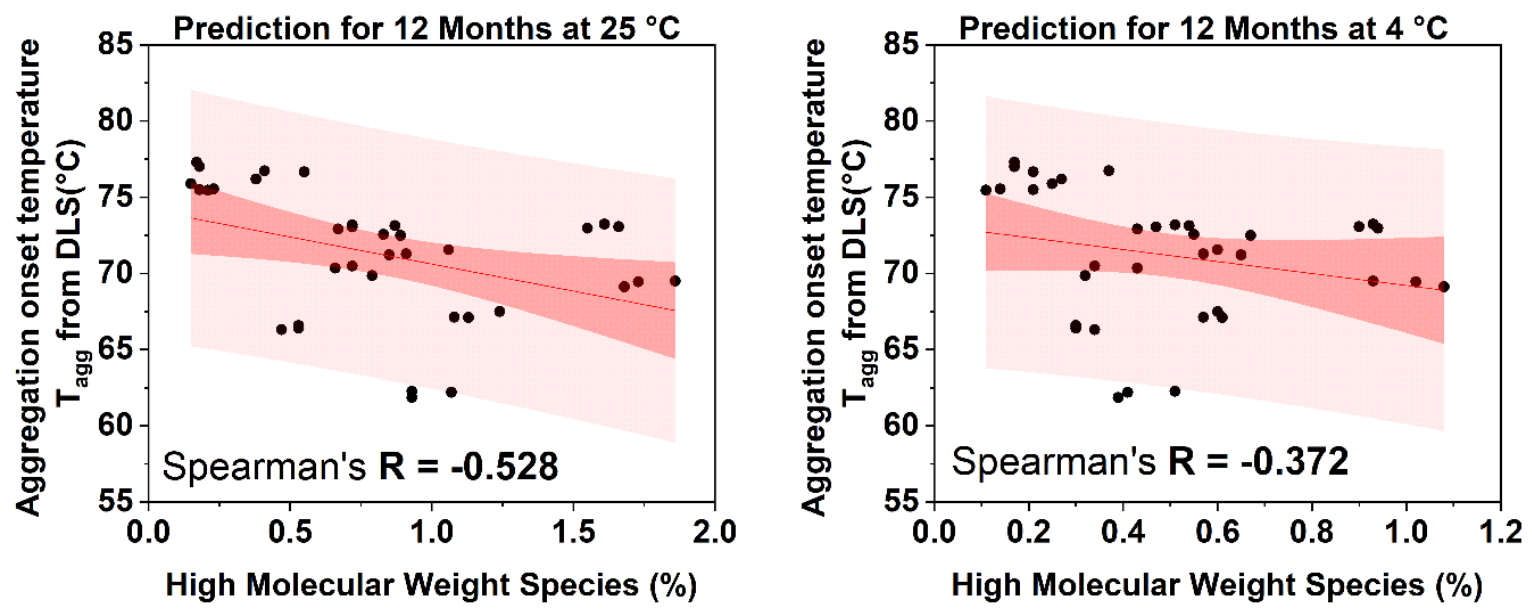
Figure S6. Correlation between the relative monomer yield of PPI03 from the ReFOLD assay and the relative content of high molecular weight species detected by size exclusion chromatography after 12 months storage at $25^{\circ} \mathrm{C}$ (left) and at $4{ }^{\circ} \mathrm{C}$ (right). The value of each replicate is shown on the graph. The solid red line is linear fit of the data, the dark red zone represents the $95 \%$ confidence interval of the fit and the light red zone the $\mathbf{9 5 \%}$ prediction interval.
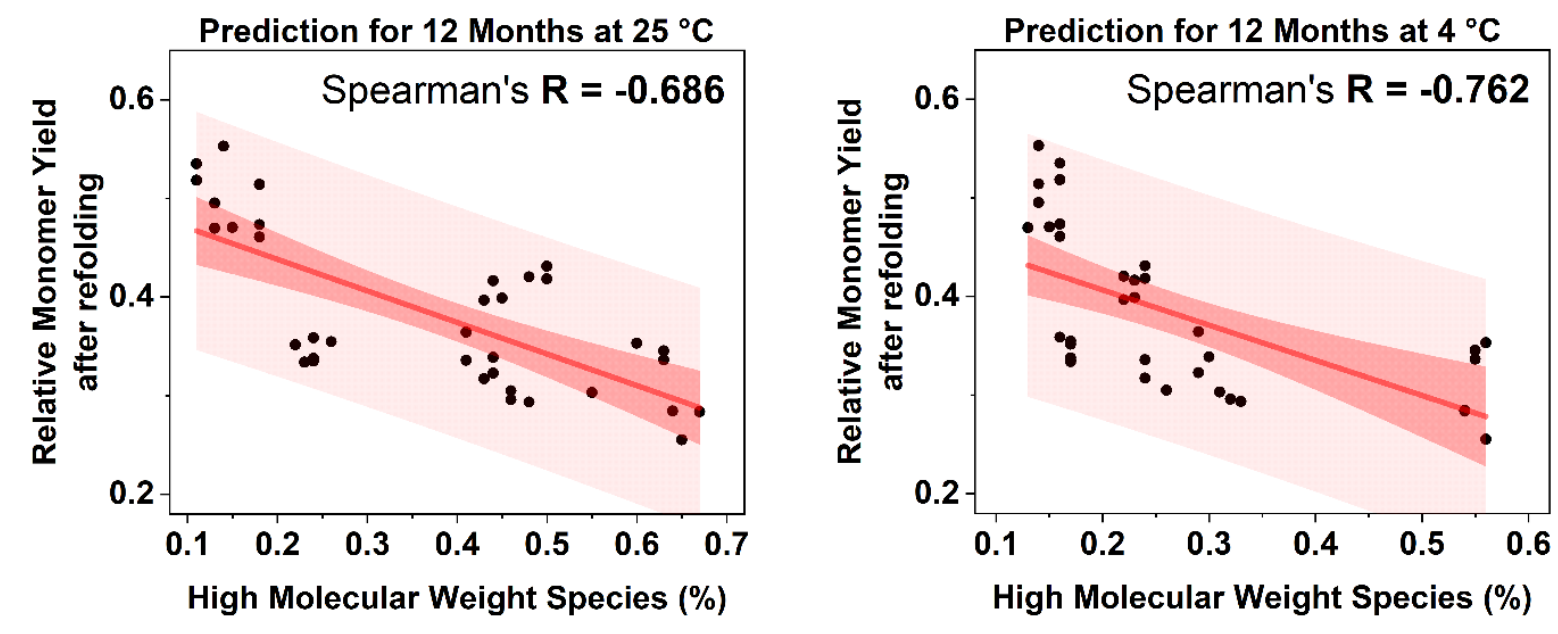

Figure S7. Correlation between the first melting temperature $\mathrm{T}_{\mathrm{m} 1}$ of PPI03 and the relative content of high molecular weight species detected by size exclusion chromatography after 12 months of storage at $25^{\circ} \mathrm{C}$ (left) and at $4{ }^{\circ} \mathrm{C}$ (right). The value of each replicate is shown on the graph. The solid red line is linear fit of the data, the dark red zone represents the $95 \%$ confidence interval of the fit and the light red zone the $95 \%$ prediction interval.

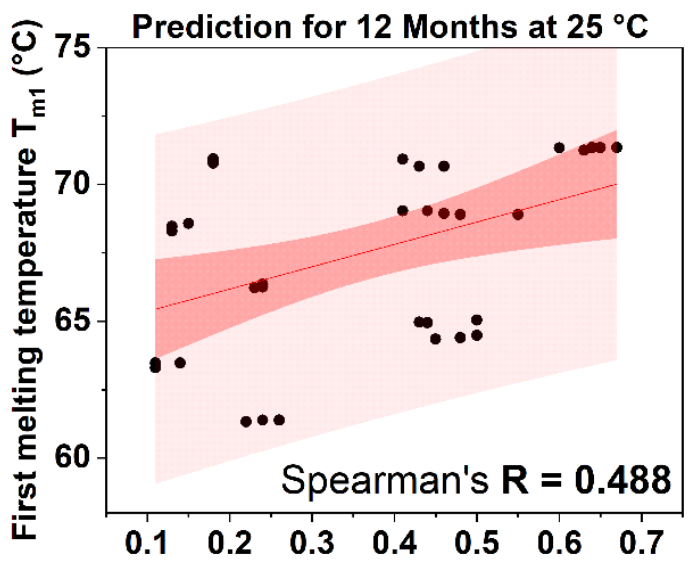

High Molecular Weight Species (\%)

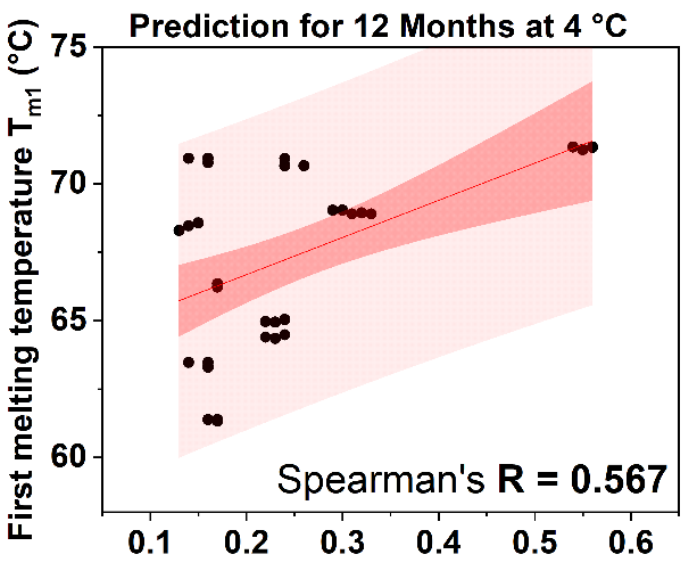

High Molecular Weight Species (\%) 
Figure S8. Correlation between the second melting temperature $\mathrm{T}_{\mathrm{m} 2}$ of PPI03 and the relative content of high molecular weight species detected by size exclusion chromatography after 12 months of storage at $25^{\circ} \mathrm{C}$ (left) and at $4{ }^{\circ} \mathrm{C}$ (right). The value of each replicate is shown on the graph. The solid red line is linear fit of the data, the dark red zone represents the $95 \%$ confidence interval of the fit and the light red zone the $95 \%$ prediction interval.

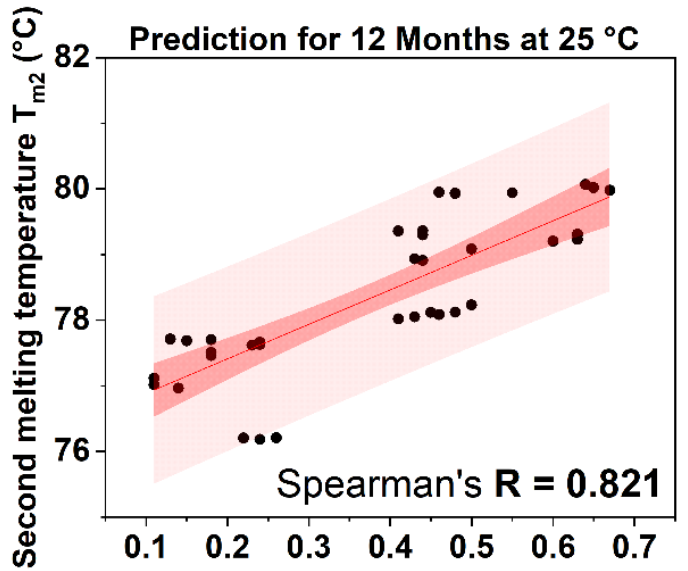

High Molecular Weight Species (\%)

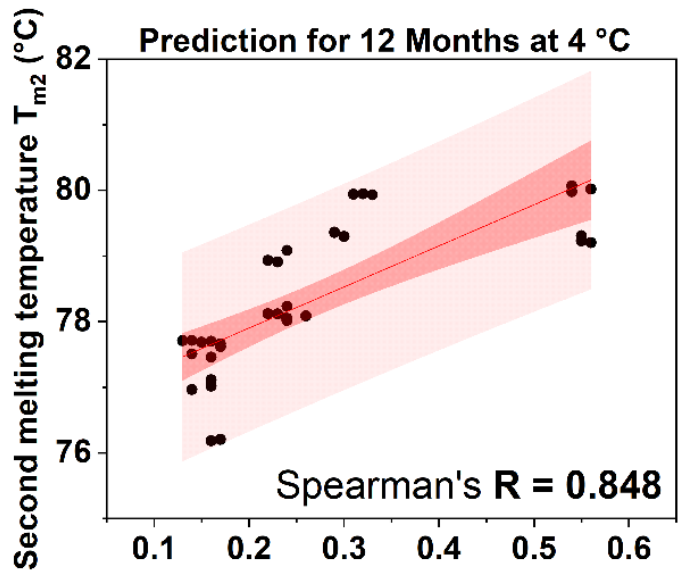

High Molecular Weight Species (\%)

Figure S9. Correlation between the aggregation onset temperature from DLS of PPI03 and the relative content of high molecular weight species detected by size exclusion chromatography after 12 months of storage at $25^{\circ} \mathrm{C}$ (left) and at $4{ }^{\circ} \mathrm{C}$ (right). The value of each replicate is shown on the graph. The solid red line is linear fit of the data, the dark red zone represents the $95 \%$ confidence interval of the fit and the light red zone the $95 \%$ prediction interval.

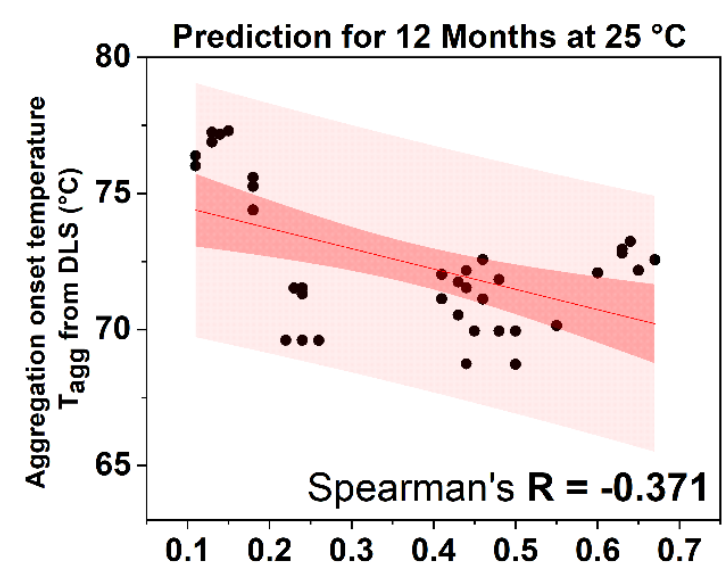

High Molecular Weight Species (\%)

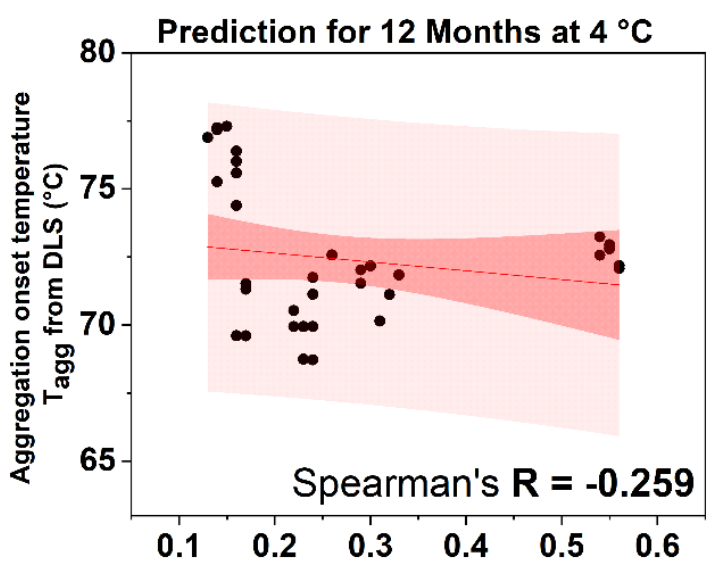

High Molecular Weight Species (\%) 
Figure S10. Isothermal unfolding curves of PPI03 in histidine (A) and citrate (B) buffer with different $\mathrm{pH}$ and different ionic strength. The symbols are means of triplicates and the bars represent the standard deviation. The lines are a guide to the eye. The concentration of LMU-1 in all samples is $0.5 \mathrm{~g} / \mathrm{L}$.
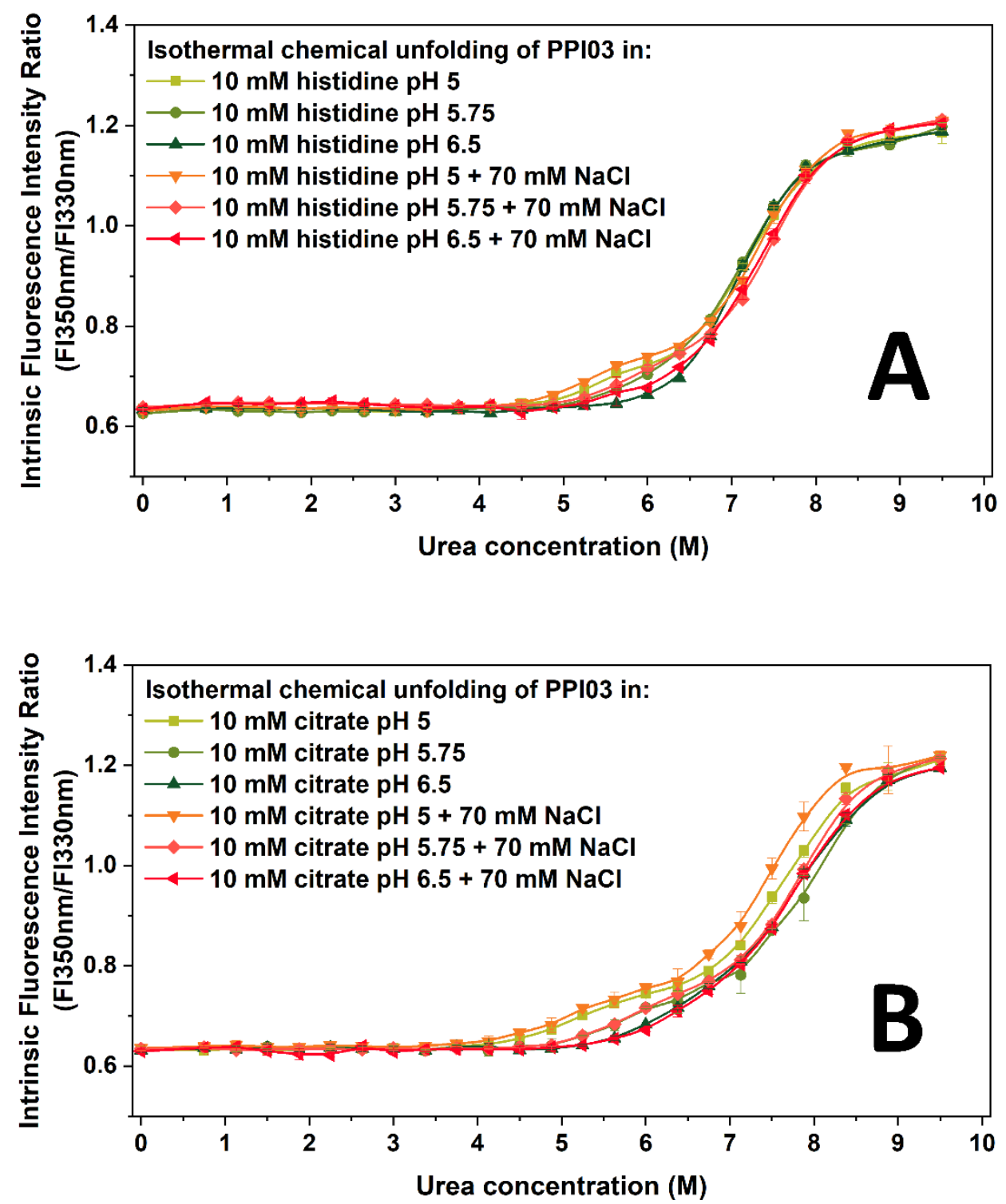
Fig S11. Thermal unfolding traces (left) and aggregation during unfolding (right) of PPI03 in presence of different concentrations of urea. The buffer is $10 \mathrm{mM}$ histidine pH 6.5 with $70 \mathrm{mM}$ sodium chloride. The concentration of LMU-1 in all samples is $0.5 \mathrm{~g} / \mathrm{L}$.
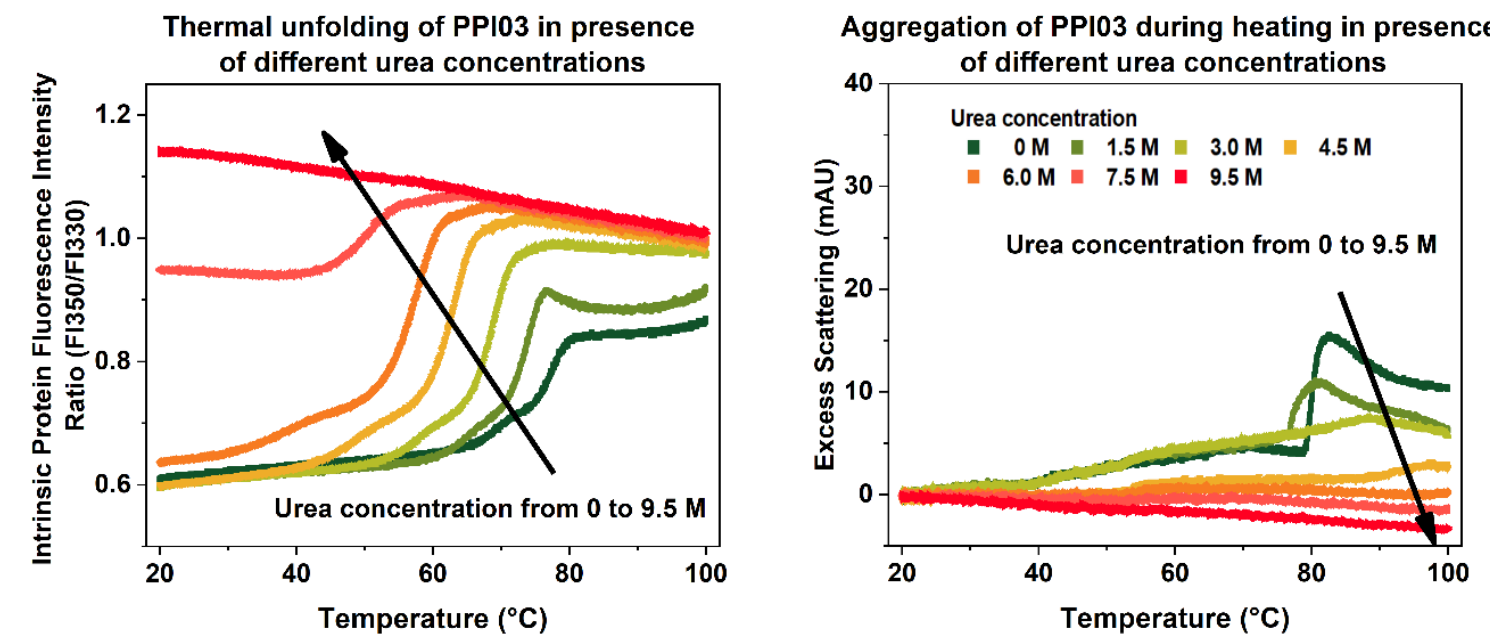

Figure S12. Isothermal aggregation of LMU-1 in presence of $9 \mathrm{M}$ urea in different formulation conditions measured by the change in the apparent protein hydrodynamic radius from DLS. The samples are prepared, measured and evaluated as described in the Supplementary data. The measurements are performed at $25{ }^{\circ} \mathrm{C}$ with 5 acquisitions of 5 seconds. The samples are corrected for viscosity using a value of $1.93 \mathrm{cP}$ for the $9 \mathrm{M}$ urea solutions.

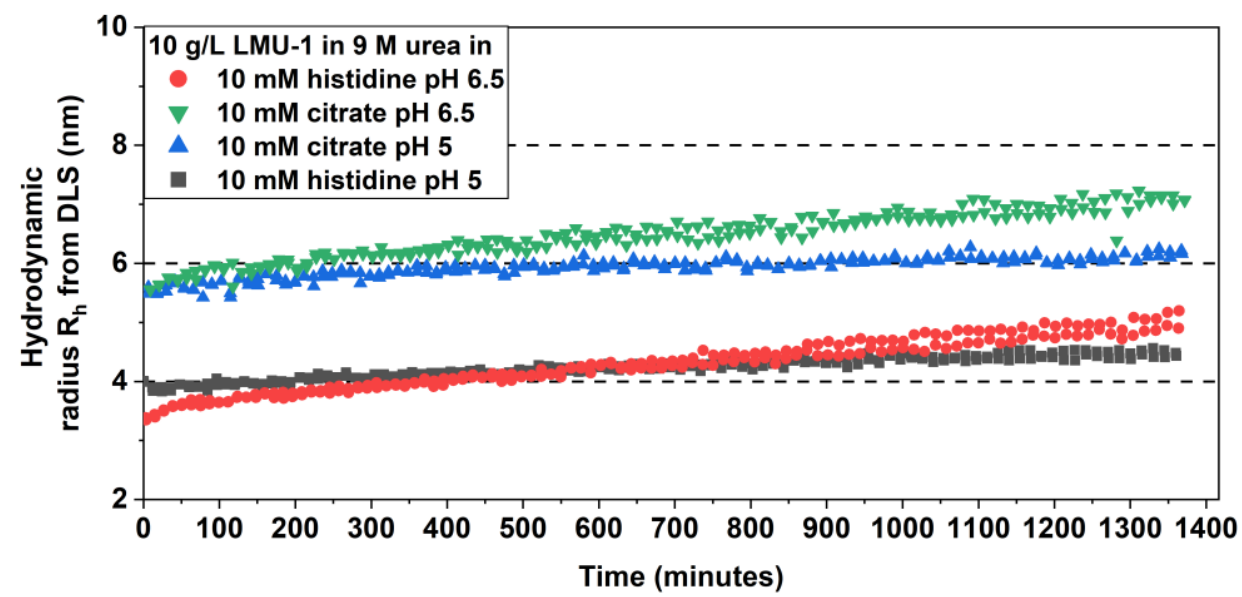


Figure S13. NearUV CD spectra of PPI03 native (green solid line), unfolded with $10 \mathrm{M}$ urea (yellow dot and dash) and refolded protein (red dot) after the ReFOLD assay was performed with $10 \mathrm{mM}$ histidine pH 5 (A), $10 \mathrm{mM}$ histidine pH 6.5 (B), $10 \mathrm{mM}$ citrate $\mathrm{pH} 5$ (C) and $10 \mathrm{mM}$ citrate pH 6.5.
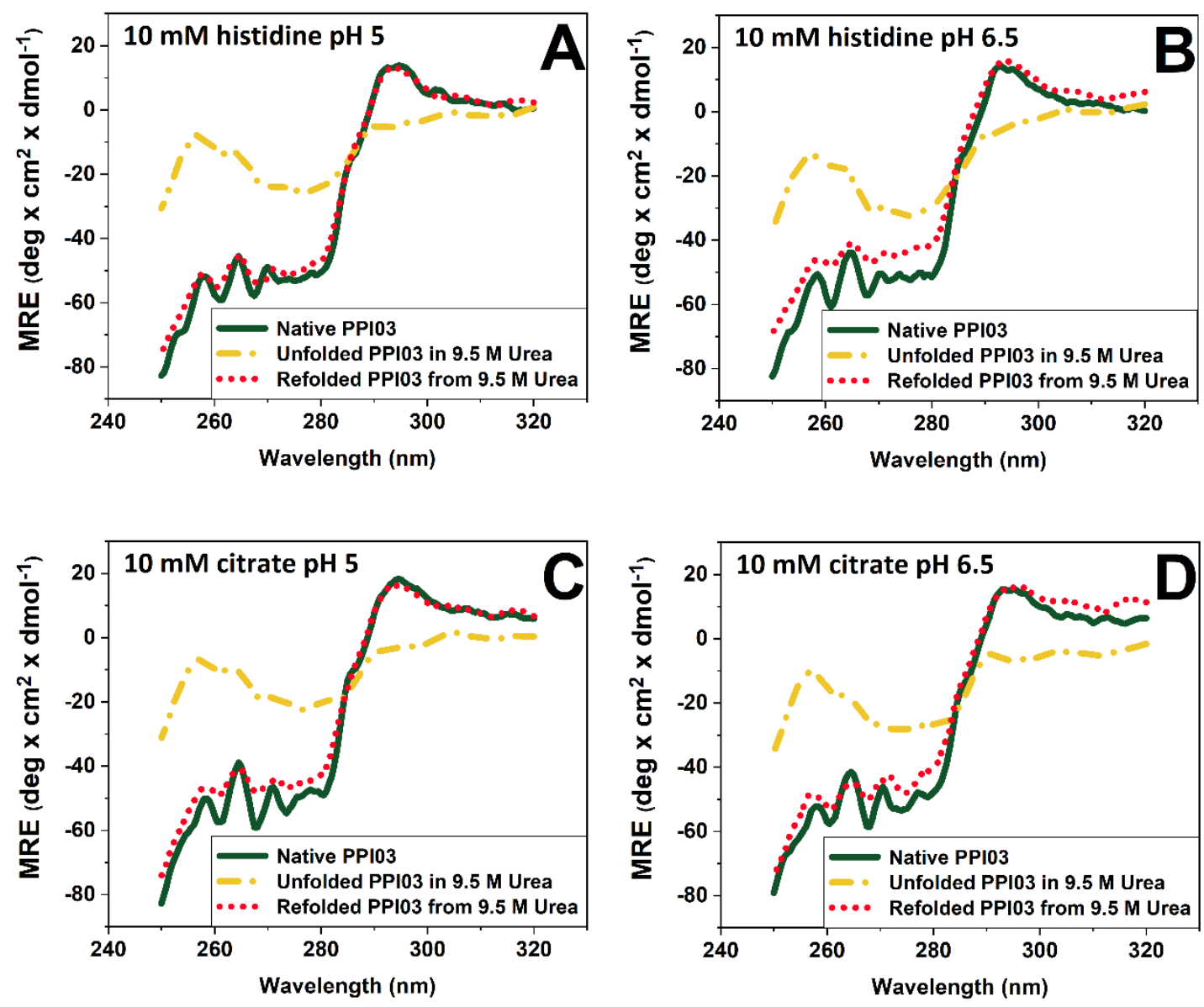